\title{
\begin{tabular}{l|l} 
MitTraries & DSpace@MIT
\end{tabular}
}

\author{
MIT Open Access Articles
}

\section{Simple Molybdenum(IV) Olefin Complexes of the Type $\operatorname{Mo}(N R)(X)(Y)$ (olefin)}

The MIT Faculty has made this article openly available. Please share how this access benefits you. Your story matters.

Citation: Marinescu, Smaranda C. et al. "Simple Molybdenum(IV) Olefin Complexes of the Type Mo(NR)(X)(Y)(olefin)." Organometallics 29.24 (2010): 6816-6828.

As Published: http://dx.doi.org/10.1021/om101003v

Publisher: American Chemical Society

Persistent URL: http://hdl.handle.net/1721.1/69660

Version: Author's final manuscript: final author's manuscript post peer review, without publisher's formatting or copy editing

Terms of Use: Article is made available in accordance with the publisher's policy and may be subject to US copyright law. Please refer to the publisher's site for terms of use. 
Simple Molybdenum(IV) Olefin Complexes of the Type Mo(NR)(X)(Y)(olefin)

by

Smaranda C. Marinescu, Annie J. King, Richard R. Schrock*, Rojendra Singh, Peter Müller, and Michael K. Takase

Contribution from

Department of Chemistry

Massachusetts Institute of Technology

Cambridge, MA 02139

$\underline{\operatorname{rrs} @ \text { mit.edu }}$

\begin{abstract}
Exposure of heptane solutions of $\mathrm{Mo}(\mathrm{NAr})\left(\mathrm{CHCMe}_{2} \mathrm{Ph}\right)\left(\mathrm{Me}_{2} \mathrm{Pyr}\right)(\mathrm{OAr})(\mathbf{1 a} ; \mathrm{Ar}=2,6-$ diisopropylphenyl), $\quad \mathrm{Mo}(\mathrm{NAr})\left(\mathrm{CHCMe}_{3}\right)\left(\mathrm{Me}_{2} \mathrm{Pyr}\right)\left[\mathrm{OCMe}\left(\mathrm{CF}_{3}\right)_{2}\right] \quad(\mathbf{1 b}), \quad$ and $\mathrm{Mo}(\mathrm{NAr})\left(\mathrm{CHCMe}_{2} \mathrm{Ph}\right)\left(\mathrm{Me}_{2} \mathrm{Pyr}\right)\left(\mathrm{OSiPh}_{3}\right)(\mathbf{1 c})$ to one atmosphere of ethylene for $12 \mathrm{~h}$ yields the ethylene complexes, $\quad \mathrm{Mo}(\mathrm{NAr})\left(\mathrm{CH}_{2} \mathrm{CH}_{2}\right)\left(\mathrm{Me}_{2} \mathrm{Pyr}\right)(\mathrm{OAr})$

(2a), $\mathrm{Mo}(\mathrm{NAr})\left(\mathrm{CH}_{2} \mathrm{CH}_{2}\right)\left(\mathrm{Me}_{2} \mathrm{Pyr}\right)\left[\mathrm{OCMe}\left(\mathrm{CF}_{3}\right)_{2}\right]$ (2b), and $\mathrm{Mo}(\mathrm{NAr})\left(\mathrm{CH}_{2} \mathrm{CH}_{2}\right)\left(\mathrm{Me}_{2} \mathrm{Pyr}\right)\left(\mathrm{OSiPh}_{3}\right)$ (2c). Addition of one equivalent of triphenylsilanol to a solution of $2 \mathbf{c}$ gives $\mathrm{Mo}(\mathrm{NAr})\left(\mathrm{CH}_{2} \mathrm{CH}_{2}\right)\left(\mathrm{OSiPh}_{3}\right)_{2}$ (3) readily. $\mathrm{Mo}(\mathrm{NAr})\left(\mathrm{CHCMe}_{2} \mathrm{Ph}\right)(\mathrm{OTf})_{2}(\mathrm{dme})$ reacts slowly with ethylene $(60 \mathrm{psi})$ in toluene at 80 ${ }^{\circ} \mathrm{C}$ to give cis and trans isomers of $\mathrm{Mo}(\mathrm{NAr})\left(\mathrm{CH}_{2} \mathrm{CH}_{2}\right)(\mathrm{OTf})_{2}(\mathrm{dme})$ (4a) in the ratio of $\sim 2($ cis $): 1$. Addition of lithium 2,5-dimethylpyrrolide to $\mathbf{4 a}$ under 1 atm of ethylene produces $\mathrm{Mo}(\mathrm{NAr})\left(\mathrm{CH}_{2} \mathrm{CH}_{2}\right)\left(\eta^{1}-\mathrm{Me}_{2} \mathrm{Pyr}\right)\left(\eta^{5}-\mathrm{Me}_{2} \mathrm{Pyr}\right)(\mathbf{5 a}) . \mathrm{Mo}(\mathrm{NAr})\left(\mathrm{CHCMe}_{2} \mathrm{Ph}\right)\left(\eta^{1}-\mathrm{MesPyr}\right)_{2}(\mathrm{MesPyr}=$ 2-mesitylpyrrolide) reacts cleanly with ethylene in benzene at $60{ }^{\circ} \mathrm{C}$ over a period of four days to give exclusively $\mathrm{Mo}(\mathrm{NAr})\left(\mathrm{CH}_{2} \mathrm{CH}_{2}\right)(\mathrm{MesPyr})_{2}$ (5b). Treatment of $\mathbf{5 b}$ with 2 equivalents of $\left(\mathrm{CF}_{3}\right)_{2} \mathrm{CHOH}$ in ether yields $\mathrm{Mo}(\mathrm{NAr})\left(\mathrm{CH}_{2} \mathrm{CH}_{2}\right)\left[\mathrm{OCH}\left(\mathrm{CF}_{3}\right)_{2}\right]_{2}\left(\mathrm{Et}_{2} \mathrm{O}\right)(\mathbf{6})$. Neat styrene reacts with $2 c$ and 3 to generate the styrene complexes, $\mathrm{Mo}(\mathrm{NAr})\left(\mathrm{CH}_{2} \mathrm{CHPh}\right)\left(\mathrm{Me}_{2} \mathrm{Pyr}\right)\left(\mathrm{OSiPh}_{3}\right)$ (7) and
\end{abstract}


$\mathrm{Mo}(\mathrm{NAr})\left(\mathrm{CH}_{2} \mathrm{CHPh}\right)\left(\mathrm{OSiPh}_{3}\right)_{2}$ (8), respectively. Similarly, the trans-3-hexene complex, $\mathrm{Mo}(\mathrm{NAr})($ trans-3-hexene $)\left(\mathrm{OSiPh}_{3}\right)_{2}(\mathbf{9 a})$, can be prepared from 3 and neat trans-3-hexene. When 3 is exposed to 1 atm of ethylene, the molybdacyclopentane species, $\mathrm{Mo}(\mathrm{NAr})\left(\mathrm{C}_{4} \mathrm{H}_{8}\right)\left(\mathrm{OSiPh}_{3}\right)_{2}(\mathbf{1 0})$, is generated. X-ray structural studies were carried out on 2c, 5a, 6, 8, 9a, and 10. All evidence suggests that alkene exchange at the Mo(IV) center is facile, followed by cis,trans isomerization and isomerization via double bond migration. In addition, trace amounts of alkylidene complexes are formed that result in slow metathesis reactions of free olefins to give (e.g.) a distribution of all possible linear olefins from an initial olefin and its double bond isomers. 


\section{Introduction}

Ethylene is a product of olefin metathesis reactions that involve one or more terminal olefins. High oxidation state molybdenum and tungsten imido alkylidene complexes ${ }^{1}$ react with ethylene to give methylidene complexes, which are the least stable alkylidenes toward bimolecular decomposition, and unsubstituted metallacyclobutane complexes, which are the most stable metallacycles toward loss of an olefin. Ethylene also has been proposed to promote rearrangement of an unsubstituted metallacyclobutane to an olefin and thereby to lead to decomposition of high oxidation state alkylidene catalysts. ${ }^{2}$

Perhaps the most informative studies concerning reactions between alkylidene complexes and ethylene in solution have employed ${ }^{13} \mathrm{C}$-labeled ethylene. Reactions between ${ }^{13} \mathrm{C}_{2} \mathrm{H}_{4}$ and tungsten biphenolate and binaphtholate catalysts have been studied most thoroughly., ${ }^{2,3}$ (Fewer studies have been reported for analogous Mo complexes. ${ }^{4}$ ) Among the species observed in solution are an unsubstituted tungstacyclobutane complex, an ethylene complex, an unsubstituted tungstacyclopentane complex, and a heterochiral dimeric methylidene complex. Ethylene has also been employed in order to study the mechanism of catalyst decomposition and formation of bimetallic species. For example, the tungstacyclobutane complex, W(NAr $\left.{ }^{\mathrm{Cl}}\right)(\mathrm{Biphen})\left(\mathrm{C}_{3} \mathrm{H}_{6}\right)\left(\mathrm{Ar}^{\mathrm{Cl}}=\right.$ 2,6- $\mathrm{Cl}_{2} \mathrm{C}_{6} \mathrm{H}_{3}$; Biphen = 6,6'-dimethyl-3,3',5,5'-tetra-t-butyl-1,1'-biphenyl-2,2'-diolate), was found to decompose to yield (inter alia) the dimeric, heterochiral methylidene complex, $\left[\mathrm{W}(\mathrm{NArCl})(\mathrm{Biphen})\left(\mu-\mathrm{CH}_{2}\right)\right]_{2}$, which decomposed further to yield homochiral $\left[\mathrm{W}\left(\mathrm{NAr}{ }^{\mathrm{Cl}}\right)(\mathrm{Biphen})\right]_{2}\left(\mu-\mathrm{CH}_{2} \mathrm{CH}_{2}\right)$, which in turn lost ethylene to yield $\left[\mathrm{W}\left(\mathrm{NAr}{ }^{\mathrm{Cl}}\right)(\mathrm{Biphen})\right]_{2}{ }^{5}$ The ethylene complexes that have been prepared in reactions between imido alkylidene complexes and ethylene and that have been isolated and structurally characterized are the five-coordinate species $\mathrm{W}\left(\mathrm{NAr}^{\mathrm{Cl}}\right)\left(\mathrm{CH}_{2} \mathrm{CH}_{2}\right)(\mathrm{Biphen})(\mathrm{THF}){ }^{5}{ }^{5} \quad \mathrm{Mo}\left(\mathrm{NAr}^{\mathrm{Cl}}\right)\left(\mathrm{CH}_{2} \mathrm{CH}_{2}\right)(\mathrm{Biphen})\left(\mathrm{Et}_{2} \mathrm{O}\right){ }^{4}, \quad$ and $\left\{\mathrm{Mo}(\mathrm{NAr})\left(\mathrm{CH}_{2} \mathrm{CH}_{2}\right)\left[\mathrm{OCMe}\left(\mathrm{CF}_{3}\right)_{2}\right](\mathrm{THF})_{3}\right\} \mathrm{B}\left(3,5-\left(\mathrm{CF}_{3}\right)_{2} \mathrm{C}_{6} \mathrm{H}_{3}\right)_{4}{ }^{6}$

There is some evidence that alkylidene complexes can be formed in reactions between Mo(IV) or W(IV) imido bisalkoxide or biphenolate complexes and ethylene. For example, vinyltributylstannane is homologated to allyltributylstannane by Mo(IV) complexes in the presence 
of ethylene. ${ }^{7}$ Although $\mathrm{Mo}\left(\mathrm{NAr}^{\mathrm{Cl}}\right)\left(\mathrm{CH}_{2} \mathrm{CH}_{2}\right)(\mathrm{rac}$-Biphen)(ether) is inactive for ring-closing diallyl ether in 10 days at $22{ }^{\circ} \mathrm{C}$, when 10 equivalents of norbornene were added to a benzene solution of 5 mol\% $\mathrm{Mo}\left(\mathrm{NAr}{ }^{\mathrm{Cl}}\right)\left(\mathrm{CH}_{2} \mathrm{CH}_{2}\right)($ rac-Biphen)(ether) and diallyl ether, a 56\% yield of 2,4-dihydrofuran was obtained in 10 days. $^{8}$

In the last several years new types of Mo and $\mathrm{W}$ imido alkylidene complexes that have the formula $\mathrm{M}(\mathrm{NR})\left(\mathrm{CHR}^{\prime}\right)\left(\mathrm{OR}^{\prime \prime}\right)(\mathrm{Pyr})$, where Pyr is a pyrrolide or substituted pyrrolide ligand and OR" usually is an aryloxide, have been prepared and explored. ${ }^{9}$ These $\underline{\text { MonoAlkoxidePyrrolide (MAP) }}$ species can be viewed as third generation high oxidation state imido alkylidene catalysts (after "first generation" bisalkoxides and "second generation" biphenolates and binaphtholates ${ }^{1}$ ). MAP species have many new features of fundamental interest, perhaps the most important of which is the presence of a stereogenic metal center. MAP species have proven to be extraordinarily reactive, 9,10 as are isoelectronic rhenium alkylidyne alkylidene species that contain a stereogenic metal center. ${ }^{11}$ Under the right circumstances many have been found to be long-lived compared to first or second generation catalysts. Initial studies of reactions between MAP species and ethylene showed that when a sterically relatively small set of ligands is present, ethylene complexes are often formed in the presence of ethylene. ${ }^{12}$

It is interesting to note that olefin complexes of the type $\mathrm{M}(\mathrm{NAr})(\mathrm{X})(\mathrm{Y})($ olefin) $(\mathrm{M}=\mathrm{Mo}$ or $\mathrm{W} ; \mathrm{X}$ or $\mathrm{Y}=$ alkoxide or $\eta^{1}$-pyrrolide) are related to $\mathrm{TaCp} * \mathrm{Cl}_{2}$ (olefin) complexes, which catalyze the dimerization of terminal olefins to tail-to-tail or head-to-tail dimers via a metallacyclopentane "ring-contraction" mechanism. ${ }^{13}$ Complexes that contain $\mathrm{Mo}(\mathrm{NAr})(\mathrm{X})(\mathrm{Y})$ or $\mathrm{W}(\mathrm{NAr})(\mathrm{X})(\mathrm{Y})$ cores also will dimerize ethylene slowly to 1-butene.,

In view of the isomeric relationship between olefin and alkylidene complexes, ${ }^{14,15,16}$ as well as the roles olefins may play in metathesis chemistry beyond the obvious role as substrates, as has been outlined above, we decided to explore routes to simple Mo(IV) ethylene complexes of the type $\operatorname{Mo}(\mathrm{NAr})(\mathrm{X})(\mathrm{Y})\left(\mathrm{CH}_{2} \mathrm{CH}_{2}\right)$ and reactions between ethylene complexes and olefins. The results of this investigation are reported here. 


\section{RESULTS}

Exposure of heptane solutions of $\mathrm{Mo}(\mathrm{NAr})\left(\mathrm{CHCMe}_{2} \mathrm{Ph}\right)\left(\mathrm{Me}_{2} \mathrm{Pyr}\right)(\mathrm{OAr})(\mathbf{1 a} ; \mathrm{Ar}=2,6-$ diisopropylphenyl, $\quad \mathrm{Me}_{2} \mathrm{Pyr} \quad$ 2,5-dimethylpyrrolide) and $\mathrm{Mo}(\mathrm{NAr})\left(\mathrm{CHCMe}_{3}\right)\left(\mathrm{Me}_{2} \mathrm{Pyr}\right)\left[\mathrm{OCMe}\left(\mathrm{CF}_{3}\right)_{2}\right](\mathbf{1 b})$ to one atmosphere of ethylene for $12 \mathrm{~h}$ led to formation of the ethylene complexes, $\mathrm{Mo}(\mathrm{NAr})\left(\mathrm{CH}_{2} \mathrm{CH}_{2}\right)\left(\mathrm{Me}_{2} \mathrm{Pyr}\right)(\mathrm{OAr}) \quad$ (2a) and $\mathrm{Mo}(\mathrm{NAr})\left(\mathrm{CH}_{2} \mathrm{CH}_{2}\right)\left(\mathrm{Me}_{2} \mathrm{Pyr}\right)\left[\mathrm{OCMe}\left(\mathrm{CF}_{3}\right)_{2}\right]$ (2b) in isolated yields of $59 \%$ and $63 \%$, respectively (equation 1). Proton NMR spectra in $\mathrm{C}_{6} \mathrm{D}_{6}$ revealed resonances for bound ethylene at $2.95(2 \mathrm{H})$, $2.60(1 \mathrm{H})$, and $1.95(1 \mathrm{H}) \mathrm{ppm}$ in $\mathbf{2 a}$ and $2.74(2 \mathrm{H}), 2.45(1 \mathrm{H}), 2.16(1 \mathrm{H}) \mathrm{ppm}$ in $\mathbf{2 b}$. The presence of four ethylene resonances (two overlapping) suggests that the ethylene does not rotate rapidly on the NMR time scale. A similar reaction between $\mathrm{Mo}(\mathrm{NAr})\left(\mathrm{CHCMe}_{2} \mathrm{Ph}\right)\left(\mathrm{Me}_{2} \mathrm{Pyr}\right)\left(\mathrm{OSiPh}_{3}\right)(\mathbf{1 c})$ and ethylene led to formation of $\mathrm{Mo}(\mathrm{NAr})\left(\mathrm{CH}_{2} \mathrm{CH}_{2}\right)\left(\mathrm{Me}_{2} \mathrm{Pyr}\right)\left(\mathrm{OSiPh}_{3}\right)$ (2c) in $70 \%$ yield (ethylene resonances at $2.87(1 \mathrm{H}), 2.70(1 \mathrm{H})$, and $2.20(2 \mathrm{H}) \mathrm{ppm})$. Experiments employing ${ }^{13} \mathrm{C}_{2} \mathrm{H}_{4}$ revealed ethylene carbon resonances at 56.3 and 60.2 ppm with $\mathrm{J}_{\mathrm{CH}}=155 \mathrm{~Hz}$ and $\mathrm{J}_{\mathrm{CC}}=39 \mathrm{~Hz}$ for $2 \mathbf{a}$, and at 56.9 and 58.0 ppm with $\mathrm{J}_{\mathrm{CH}}=153 \mathrm{~Hz}$ and $\mathrm{J}_{\mathrm{CC}}=37 \mathrm{~Hz}$ for 2c. These chemical shifts and $\mathrm{J}_{\mathrm{CH}}$ values are similar to those reported in ethylene complexes noted earlier ${ }^{5,6}$ and others reported here.
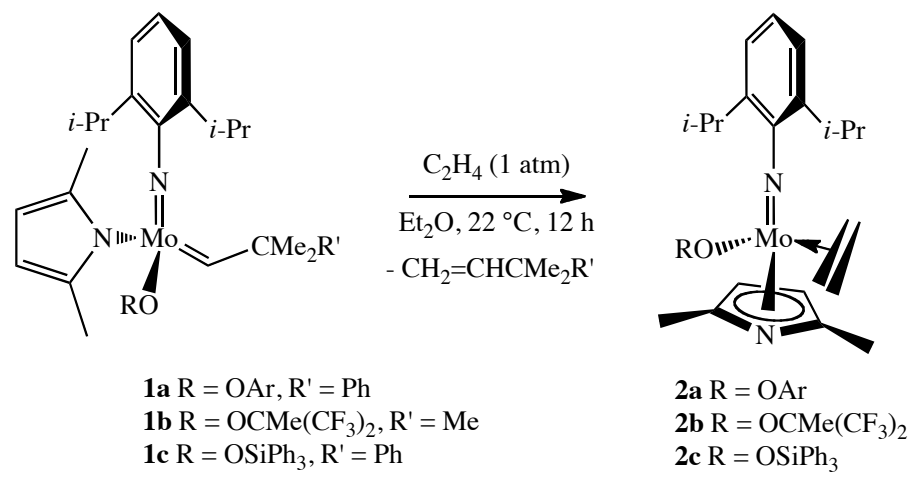

The results of a single crystal X-ray structural study of $\mathbf{2 c}$ are shown in Figure 1. The C(1)$\mathrm{C}(2)$ bond length is $1.420(3) \AA$, which should be compared to the ethylene C-C bond lengths in $\mathrm{Mo}\left(\mathrm{N}-2,6-\mathrm{Cl}_{2} \mathrm{C}_{6} \mathrm{H}_{3}\right)\left(\mathrm{CH}_{2} \mathrm{CH}_{2}\right)(\mathrm{Biphen})\left(\mathrm{Et}_{2} \mathrm{O}\right) \quad(1.400(13) \quad \AA),{ }^{4} \quad \mathrm{~W}\left(\mathrm{NAr}^{\mathrm{Cl}}\right)\left(\mathrm{CH}_{2} \mathrm{CH}_{2}\right)(\mathrm{Biphen})(\mathrm{THF})$ $(1.452(3) \AA),{ }^{5}$ and $\left\{\mathrm{Mo}(\mathrm{NAr})\left(\mathrm{CH}_{2} \mathrm{CH}_{2}\right)\left[\mathrm{OC}\left(\mathrm{CF}_{3}\right)_{2} \mathrm{Me}\right](\mathrm{THF})_{3}\right\}^{+}(1.408(4) \AA)^{6}{ }^{6}$ The imido ligand 
bends $\left(\mathrm{Mo}(1)-\mathrm{N}(1)-\mathrm{C}(11)=163.09(15)^{\circ}\right)$ in response to some significant steric interaction between the triphenylsiloxide and the 2,6-diisopropylphenylimido ligand. The ethylene is oriented so that its $\mathrm{C}-\mathrm{C}$ axis is essentially perpendicular to the $\mathrm{Mo}(1)-\mathrm{N}(1)$ axis $\left(\mathrm{N}(1)-\mathrm{Mo}(1)-\mathrm{C}(1)=98.75(9)^{\circ}, \mathrm{N}(1)-\right.$ $\left.\operatorname{Mo}(1)-C(2)=97.89(8)^{\circ}\right)$.

A reaction between $1 \mathrm{c}$ and propylene in $\mathrm{C}_{6} \mathrm{D}_{6}$ led to formation of the ethylidene complex $\mathrm{Mo}(\mathrm{NAr})(\mathrm{CHMe})\left(\mathrm{Me}_{2} \mathrm{Pyr}\right)\left(\mathrm{OSiPh}_{3}\right)$ initially, as judged from appearance of a new alkylidene quartet at $12.32 \mathrm{ppm}$, along with $\mathbf{2 c}$ and other species, but after 1 day at room temperature only $\mathbf{2 c}$ is observed along with propylene and expected metathesis products (2-butenes, $\mathrm{H}_{2} \mathrm{C}=\mathrm{CHCMe}_{2} \mathrm{Ph}$, etc.). Since ethylene is generated in the metathesis reaction and since ethylene is the smallest and most reactive olefin, the ultimate product or products are derived from ethylene.

Addition of $\mathrm{CD}_{2} \mathrm{CD}_{2}(1 \mathrm{~atm})$ to a $\mathrm{C}_{6} \mathrm{H}_{6}$ solution of $2 \mathrm{c}$ led to immediate formation of $\mathrm{Mo}(\mathrm{NAr})\left(\mathrm{CD}_{2} \mathrm{CD}_{2}\right)\left(\mathrm{Me}_{2} \mathrm{Pyr}\right)\left(\mathrm{OSiPh}_{3}\right)$, according to ${ }^{2} \mathrm{H}$ NMR spectroscopy. This observation confirms that ethylene exchanges readily in $\mathbf{2 c}$, either through direct displacement of ethylene by $\mathrm{CD}_{2} \mathrm{CD}_{2}$ in a five-coordinate intermediate or through rapid formation and breakup of an intermediate five-coordinate molybdacyclopentane (vide infra). Rapid exchange can also be observed employing ${ }^{13} \mathrm{C}$ NMR and ${ }^{13} \mathrm{C}_{2} \mathrm{H}_{4}$.

Addition of one equivalent of triphenylsilanol to a solution of $2 \mathbf{c}$ led to an immediate color change from red to purple. A proton NMR spectrum revealed two pseudo quartets at 2.74 and 1.99 ppm which integrate as two protons each for bound ethylene in mirror symmetric $\mathrm{Mo}(\mathrm{NAr})\left(\mathrm{CH}_{2} \mathrm{CH}_{2}\right)\left(\mathrm{OSiPh}_{3}\right)_{2}$ (3) (equation 2). Protonolysis of pyrrolide ligands in these

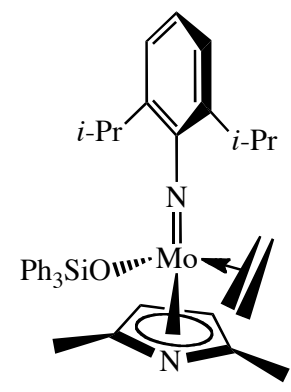

2c

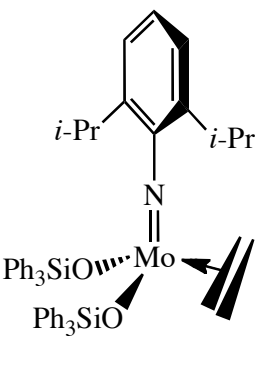

3 
circumstances has been proposed to require coordination of the alcohol oxygen to the metal before proton migration, ${ }^{9 \mathrm{e}}$ which in turn suggests that the $18 \mathrm{e}$ count in $\mathbf{2 c}$ is first reduced to $14 \mathrm{e}$ through ready formation of intermediate $\mathrm{Mo}(\mathrm{NAr})\left(\mathrm{CH}_{2} \mathrm{CH}_{2}\right)\left(\eta^{1}-\mathrm{Me}_{2} \mathrm{Pyr}\right)\left(\mathrm{OSiPh}_{3}\right)$.

In order to prepare potentially a large variety of ethylene complexes we attempted to prepare an ethylene complex through a reaction between $\mathrm{Mo}(\mathrm{NAr})\left(\mathrm{CHCMe}_{2} \mathrm{Ph}\right)(\mathrm{OTf})_{2}(\mathrm{dme})$ and ethylene. $\mathrm{Mo}(\mathrm{NAr})\left(\mathrm{CHCMe}_{2} \mathrm{Ph}\right)(\mathrm{OTf})_{2}(\mathrm{dme})$ was found to react slowly with ethylene (60 psi) in toluene at 80 ${ }^{\circ} \mathrm{C}$. After two days, a red ethylene complex can be isolated in $86 \%$ yield. The ${ }^{1} \mathrm{H}$ NMR spectrum revealed several multiplet resonances between $4 \mathrm{ppm}$ and $2.5 \mathrm{ppm}$ that could be ascribed to an ethylene ligand, while the ${ }^{19} \mathrm{~F}$ NMR spectrum showed three singlet resonances at $\delta-78.26,-78.30$, and -78.59 for triflate ligands in approximately a $1: 1: 1$ ratio. All data are consistent with the reaction between $\mathrm{Mo}(\mathrm{NAr})\left(\mathrm{CHCMe}_{2} \mathrm{Ph}\right)(\mathrm{OTf})_{2}(\mathrm{dme})$ and ethylene to give cis and trans isomers of $\mathrm{Mo}(\mathrm{NAr})\left(\mathrm{CH}_{2} \mathrm{CH}_{2}\right)(\mathrm{OTf})_{2}(\mathrm{dme})(\mathbf{4 a})$ in the ratio of 2:1, respectively (equation 3). The reaction between $\mathrm{Mo}(\mathrm{NAr})(\mathrm{OTf})_{2}\left(\mathrm{CHCMe}_{2} \mathrm{Ph}\right)(\mathrm{dme})$ and ethylene most likely proceeds through metathesis to yield $\mathrm{Mo}(\mathrm{NAr})(\mathrm{OTf})_{2}\left(\mathrm{CH}_{2}\right)(\mathrm{dme})$, which then decomposes in the presence of ethylene to give the observed product. To our knowledge the reaction shown in equation 3 is the only metathetical reaction of $\mathrm{Mo}(\mathrm{NAr})(\mathrm{OTf})_{2}\left(\mathrm{CHCMe}_{2} \mathrm{Ph}\right)(\mathrm{dme})$ to have been reported. Using a similar procedure (1 atm ethylene; $\left.60^{\circ} \mathrm{C}, 6 \mathrm{~h}\right), \mathrm{Mo}(\mathrm{NAd})\left(\mathrm{CH}_{2} \mathrm{CH}_{2}\right)(\mathrm{OTf})_{2}(\mathrm{dme})(\mathbf{4 b})$ can be obtained as approximately a 2:1 mixture of cis and trans isomers, respectively.

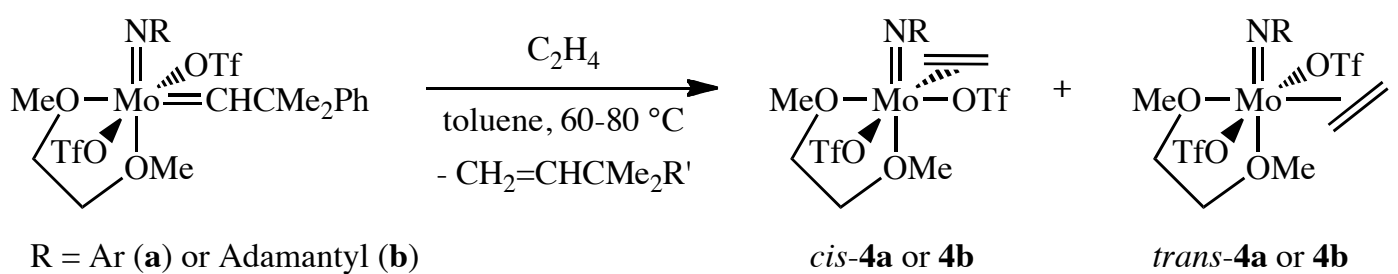

Addition of lithium 2,5-dimethylpyrrolide to $4 \mathbf{a}$ under $1 \mathrm{~atm}$ of ethylene led to formation of $\mathrm{Mo}(\mathrm{NAr})\left(\mathrm{CH}_{2} \mathrm{CH}_{2}\right)\left(\eta^{1}-\mathrm{Me}_{2} \mathrm{Pyr}\right)\left(\eta^{5}-\mathrm{Me}{ }_{2} \mathrm{Pyr}\right)(\mathbf{5 a})$ (equation 4). If the reaction is attempted in the absence of ethylene a significant amount of decomposition is observed. Compound 5a could not be 
prepared through a reaction between $\mathrm{Mo}(\mathrm{NAr})\left(\mathrm{CHCMe}_{2} \mathrm{Ph}\right)\left(\eta^{1}-\mathrm{Me}_{2} \mathrm{Pyr}\right)\left(\eta^{5}-\mathrm{Me}_{2} \mathrm{Pyr}\right)$ and ethylene (1 atm) at $80^{\circ} \mathrm{C}$. Two ethylene resonances were found at $51.3 \mathrm{ppm}$ and $48.1 \mathrm{ppm}$. A single crystal X-ray structural study of $\mathbf{5 a}$ (Figure 2) confirms that the pyrrolide ligands are bound in an $\eta^{1}$ and $\eta^{5}$ manner. The $\mathrm{C}(1)-\mathrm{C}(2)$ bond length is $1.404(4) \AA$. The $\mathrm{N}(1)-\mathrm{Mo}(1)-\mathrm{C}(1)$ and $\mathrm{N}(1)-\mathrm{Mo}(1)-\mathrm{C}(2)$ angles $\left(87.32(8)^{\circ}\right.$ and $101.17(8)^{\circ}$, respectively) suggest that ethylene is twisted a few degrees from being perpendicular to the Mo-N(1) bond.

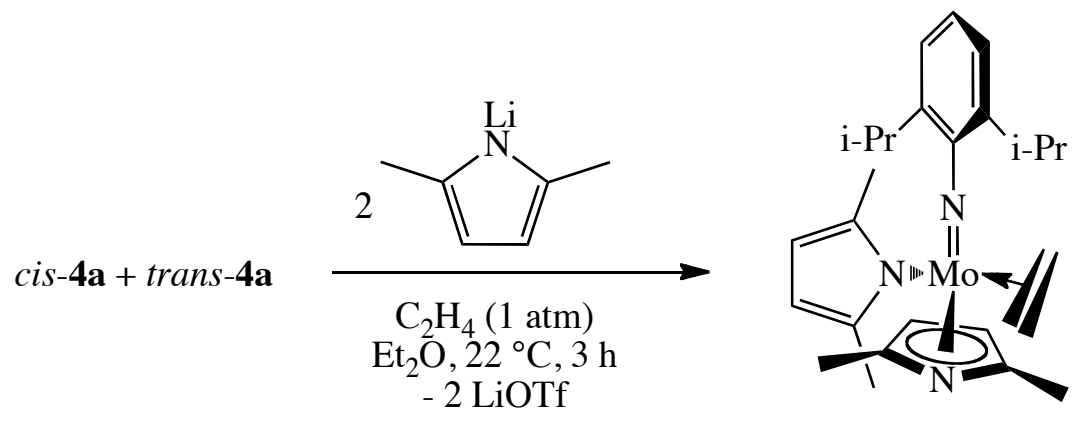

$5 \mathbf{a}$

In contrast to the failure to prepare 5a through a reaction between $\mathrm{Mo}(\mathrm{NAr})\left(\mathrm{CHCMe}_{2} \mathrm{Ph}\right)\left(\mathrm{Me}_{2} \mathrm{Pyr}\right)_{2}$ and ethylene, $\mathrm{Mo}(\mathrm{NAr})\left(\mathrm{CHCMe}_{2} \mathrm{Ph}\right)\left(\eta^{1}-\mathrm{MesPyr}\right)_{2}{ }^{6}(\mathrm{MesPyr}=2-$ mesitylpyrrolide) reacts cleanly with ethylene in benzene at $60{ }^{\circ} \mathrm{C}$ over a period of four days to give $\mathrm{Mo}(\mathrm{NAr})\left(\mathrm{CH}_{2} \mathrm{CH}_{2}\right)(\mathrm{MesPyr})_{2}(\mathbf{5 b})$ in $71 \%$ isolated yield (equation 5). The higher reactivity of

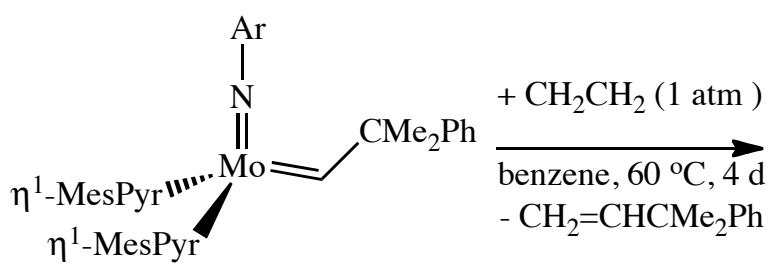

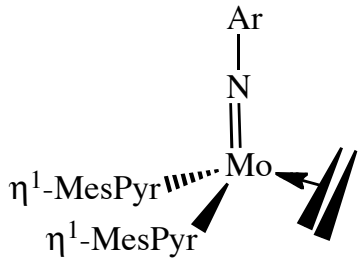

$5 b$

$\mathrm{Mo}(\mathrm{NAr})\left(\mathrm{CHCMe}_{2} \mathrm{Ph}\right)\left(\eta^{1}-\mathrm{MesPyr}\right)_{2}$ toward ethylene can be ascribed to the fact that it is a 14 electron species, in contrast to 5a. One ethylene carbon resonance was found at $53.9 \mathrm{ppm}$ with $\mathrm{J}_{\mathrm{CH}}=$ $160 \mathrm{~Hz}$. Proton NMR spectra reveal multiplets at $2.45 \mathrm{ppm}$ and $1.96 \mathrm{ppm}$ for the ethylene protons, consistent with the 2-mesitylpyrrolide ligands in $\mathbf{5 b}$ being bound in an $\eta^{1}$ manner, as found in $\mathrm{Mo}(\mathrm{NAr})\left(\mathrm{CHCMe}_{2} \mathrm{Ph}\right)\left(\eta^{1}-\mathrm{MesPyr}\right)_{2}{ }^{6} \quad$ As a demonstration that $\mathbf{5 b}$ can be employed as a 
precursor to other bisalkoxide ethylene complexes, 5b was treated with 2 equivalents of $\mathrm{HOCH}\left(\mathrm{CF}_{3}\right)_{2}$ in ether to yield $\mathrm{Mo}(\mathrm{NAr})\left(\mathrm{CH}_{2} \mathrm{CH}_{2}\right)\left[\mathrm{OCH}\left(\mathrm{CF}_{3}\right)_{2}\right]_{2}\left(\mathrm{Et}_{2} \mathrm{O}\right)(6)$ in $41 \%$ isolated yield after recrystallization. As judged from the proton NMR spectrum, 6 contains a mirror plane of symmetry on the NMR time scale; the equivalent alkoxides each contain two inequivalent $\mathrm{CF}_{3}$ groups; two ethylene proton resonances are observed at $2.64 \mathrm{ppm}$ and $1.83 \mathrm{ppm}$. An ether adduct of the bishexafluoroisopropoxide imido alkylidene complex is formed as a consequence of the relatively small size of the hexafluoroisopropoxide ligand..$^{17,18}$

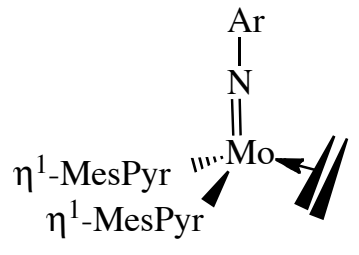

5b

$$
\begin{gathered}
+\underset{\left(\mathrm{CF}_{3}\right)_{2} \mathrm{CHOH}}{\longrightarrow} \overrightarrow{\mathrm{Et}_{2} \mathrm{O}, 5 \text { min, } 23^{\circ} \mathrm{C}} \\
-22,5 \text {-dimethylpyrrole }
\end{gathered}
$$

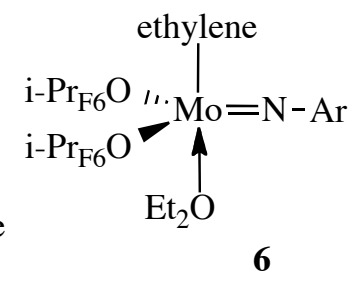

The structure of $\mathrm{Mo}(\mathrm{NAr})\left(\mathrm{CH}_{2} \mathrm{CH}_{2}\right)\left(\mathrm{O}-\mathrm{i}-\mathrm{Pr}_{\mathrm{F} 6}\right)_{2}\left(\mathrm{Et}_{2} \mathrm{O}\right)$ is best described as a distorted trigonal bipyramid in which the alkoxide and the imido ligands are in equatorial positions (Figure 3). The sum of the angles between the equatorial ligands is $351.6^{\circ}$ and they are all displaced slightly toward the ether oxygen as a consequence of the long Mo- $\mathrm{O}_{\text {ether }}$ bond length (2.3071(14) $\AA$ ) relative to Mo$\mathrm{C}_{\text {ethylene }}$ bond lengths (2.181(2) and 2.178(2) $\AA$ ). The $\mathrm{C}(1)-\mathrm{C}(2)$ distance is 1.409(3) $\AA$, which is characteristic of other ethylene complexes discussed here. The trans relationship of the ether and ethylene might suggest that a five-coordinate intermediate in which (especially large) imido and alkoxide ligands occupy equatorial positions is the most facile mechanism of displacing one two electron ligand displaces another, including one olefin by another (vide infra). It should be noted that the planar three-coordinate monomeric species, $\mathrm{W}(\mathrm{N}-\mathrm{t}-\mathrm{Bu})\left[\mathrm{OSi}(\mathrm{t}-\mathrm{Bu})_{3}\right]_{2}$, which is analogous to the central core of $\mathbf{6}$, is known. ${ }^{19}$

When a sample of 6 in benzene- $d_{6}$ was degassed and exposed to $1 \mathrm{~atm}$ of ${ }^{13} \mathrm{C}$-ethylene, a ${ }^{13} \mathrm{C}$ NMR spectrum suggested that a metallacyclopentane complex is formed on the basis of a $\mathrm{C}_{\alpha}$ 
resonance at $78.54 \mathrm{ppm}\left(J_{\mathrm{CH}}=134 \mathrm{~Hz}\right)$ and a $\mathrm{C}_{\beta}$ resonance at $39.21 \mathrm{ppm}\left(J_{\mathrm{CH}}=127 \mathrm{~Hz}\right)$. In a proton NMR spectrum prepared employing unlabeled ethylene at room temperature only broad resonances were observed for the metallacycle and ethylene protons. When all volatile components were removed from the sample the residue was found to consist of $\mathbf{6}$. An X-ray structural study of an isolated molybdacyclopentane complex is reported later in this paper.

In the interest of isolating other olefin complexes we treated 2c with neat styrene. Dry styrene was vacuum transferred to a Schlenk flask charged with solid $\mathrm{Mo}(\mathrm{NAr})\left(\mathrm{CH}_{2} \mathrm{CH}_{2}\right)\left(\mathrm{Me}_{2} \mathrm{Pyr}\right)\left(\mathrm{OSiPh}_{3}\right)(\mathbf{2 c})$. Removal of all volatiles in vacuo after 15 minutes gave a grey residue whose proton NMR spectrum in $\mathrm{C}_{6} \mathrm{D}_{6}$ suggested that the product, $\mathrm{Mo}(\mathrm{NAr})\left(\mathrm{CH}_{2} \mathrm{CHPh}\right)\left(\mathrm{Me}_{2} \mathrm{Pyr}\right)\left(\mathrm{OSiPh}_{3}\right)(7)$, was a mixture of four isomers. Four isomers of $7 \mathrm{can}$ be rationalized in view of the presence of a stereogenic metal center, enantiotopic styrene faces, and no rotation of styrene on the NMR time scale. The major isomer $(\sim 30 \%)$ displays olefinic proton resonances at $4.23(\mathrm{t}, 1 \mathrm{H}), 3.08(\mathrm{dd}, 1 \mathrm{H})$, and $2.40(\mathrm{dd}, 1 \mathrm{H}) \mathrm{ppm}$. We were not able to obtain a crystalline sample of 7 suitable for an X-ray study.

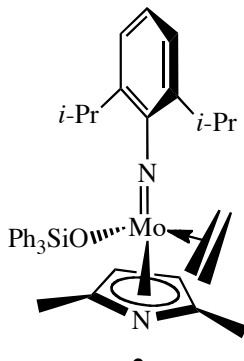

2c

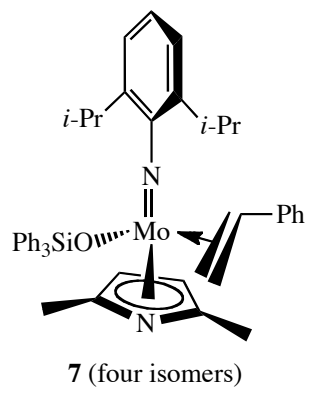

The reaction between purple $\mathrm{Mo}(\mathrm{NAr})\left(\mathrm{CH}_{2} \mathrm{CH}_{2}\right)\left(\mathrm{OSiPh}_{3}\right)_{2}(3)$ and neat, freshly dried styrene immediately yielded a green solution from which a green product could be obtained upon removal of all volatiles in vасио. Recrystallization of the residue from pentane yielded green crystals of $\mathrm{Mo}(\mathrm{NAr})\left(\mathrm{CH}_{2} \mathrm{CHPh}\right)\left(\mathrm{OSiPh}_{3}\right)_{2}\left(\mathbf{8}\right.$, equation 8), the proton NMR spectrum of which in $\mathrm{C}_{6} \mathrm{D}_{6}$ showed two isomers to be present in the ratio of 2:1. The major isomer displays olefinic proton resonances at $3.58(\mathrm{t}, 1 \mathrm{H}), 3.28(\mathrm{dd}, 1 \mathrm{H})$, and $2.44(\mathrm{dd}, 1 \mathrm{H}) \mathrm{ppm}$ for the bound styrene, while olefinic proton 
resonances for the minor isomer are found at $4.64(\mathrm{t}, 1 \mathrm{H}), 2.99(\mathrm{dd}, 1 \mathrm{H})$, and $2.26(\mathrm{dd}, 1 \mathrm{H}) \mathrm{ppm}$. Compound 8 also can be prepared by treating $\mathrm{Mo}(\mathrm{NAr})\left(\mathrm{CH}_{2} \mathrm{CHPh}\right)\left(\mathrm{Me}_{2} \mathrm{Pyr}\right)\left(\mathrm{OSiPh}_{3}\right)$ (7) with 1 equiv of $\mathrm{Ph}_{3} \mathrm{SiOH}$.

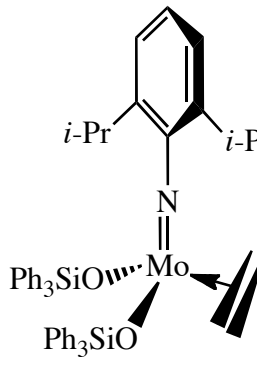

3

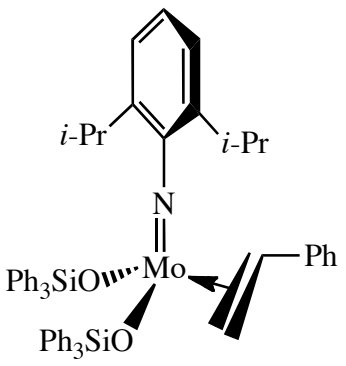

8 (two isomers, 2:1)

An X-ray structural study of a single crystal of $\mathbf{8}$ showed it to be the isomer in which the phenyl ring points toward the imido ligand (Figure 4). The styrene is oriented perpendicular to the $\operatorname{Mo}(1)-\mathrm{N}(1)$ axis $\left(\mathrm{N}(1)-\mathrm{Mo}(1)-\mathrm{C}(1)=98.49(10)^{\circ}\right.$ and $\left.\mathrm{N}(1)-\mathrm{Mo}(1)-\mathrm{C}(2)=98.76(10)^{\circ}\right)$ with $\mathrm{C}(1)-\mathrm{C}(2)$ $=1.433(4) \AA$.

A reaction between $\mathrm{Mo}(\mathrm{NAr})\left(\mathrm{CH}_{2} \mathrm{CH}_{2}\right)\left(\mathrm{OSiPh}_{3}\right)_{2}(3)$ and neat trans-3-hexene immediately produced an indigo colored hexene complex (equation 9) whose NMR spectrum in $\mathrm{C}_{6} \mathrm{D}_{6}$ revealed the presence of 2 isomers in the ratio of 4:1. The major isomer displays two olefinic multiplets between 3.5 and 2 ppm, consistent with the formation of $\mathrm{Mo}(\mathrm{NAr})\left(\mathrm{OSiPh}_{3}\right)_{2}$ (trans-3-hexene) (9a, equation 9). Crystals of 9a could be obtained through recrystallization of crude 9. An X-ray structural study of the major isomer reveals it to have the expected structure (Figure 5).

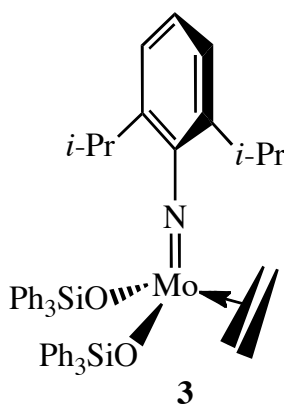

3

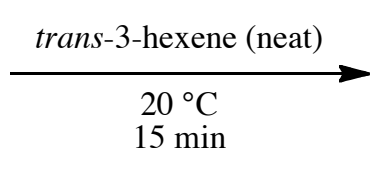

$20{ }^{\circ} \mathrm{C}$
$15 \mathrm{~min}$

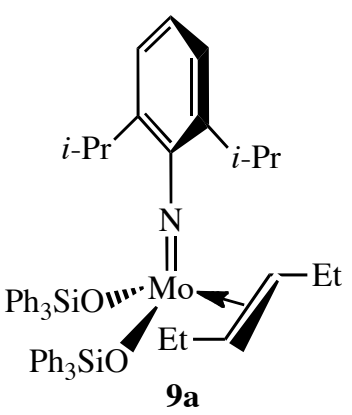


The most logical proposal is for the second isomer of 9 to be Mo(NAr)(cis-3hexene) $\left(\mathrm{OSiPh}_{3}\right)_{2}(\mathbf{9 b})$. Treatment of $\mathbf{3}$ with neat cis-3-hexene led to a 1:1 mixture of $\mathbf{9 a}$ and what we propose to be $\mathrm{Mo}(\mathrm{NAr})($ cis-3-hexene $)\left(\mathrm{OSiPh}_{3}\right)_{2}(\mathbf{9 b})$ on the basis of its mirror symmetry. Over a period of $5 \mathrm{~h}$ the mixture evolved into approximately the same 4:1 mixture of $\mathbf{9 a}$ and $9 \mathbf{b}$ formed upon treatment of $\mathbf{3}$ with trans-3-hexene. Therefore 9a and $\mathbf{9 b}$ are in slow equilibrium with the position of that equilibrium being approximately what one would predict on the basis of the relative energies of the free olefins. After $12 \mathrm{~h}$ the ${ }^{1} \mathrm{H}$ NMR spectrum reveals other olefinic resonances that correspond to the initial resonances in the spectrum of $\mathrm{Mo}(\mathrm{NAr})(2$-hexene $)\left(\mathrm{OSiPh}_{3}\right)_{2}$, which is prepared independently from $\mathbf{3}$ and neat trans-2-hexene. Therefore we propose that 9a and 9b slowly are converted into a complex mixture that contain $\mathrm{Mo}(\mathrm{NAr})($ trans-2-hexene $)\left(\mathrm{OSiPh}_{3}\right)_{2}(\mathbf{9 c})$ (2 isomers) and $\mathrm{Mo}(\mathrm{NAr})($ cis-2-hexene $)\left(\mathrm{OSiPh}_{3}\right)_{2}(\mathbf{9 d})$ (2 isomers). An even more complex mixture (up to eight isomers eventually) is formed when $\mathbf{3}$ is treated with neat 1-hexene; we propose that $\mathrm{Mo}(\mathrm{NAr})(1-$ hexene $)\left(\mathrm{OSiPh}_{3}\right)_{2}$ forms initially and is then converted into isomers of $\mathrm{Mo}(\mathrm{NAr})(2-$ hexene $)\left(\mathrm{OSiPh}_{3}\right)_{2}$ and $\mathrm{Mo}(\mathrm{NAr})(3$-hexene $)\left(\mathrm{OSiPh}_{3}\right)_{2}$.

When a sample of $\mathbf{3}$ in toluene- $d_{8}$ was degassed and exposed to $1 \mathrm{~atm}$ of ethylene, the color changed from purple to red-orange. At $20^{\circ} \mathrm{C}$, two broad resonances were observed at $\sim 3.1$ and $\sim 2.5 \mathrm{ppm}$, which integrate to four protons each (Figure 6). At $-20^{\circ} \mathrm{C}$, four resonances are observed at 3.11, 3.06, 2.58, and $2.41 \mathrm{ppm}$ integrating as two protons each, consistent with formation of the metallacyclopentane species, $\mathrm{Mo}(\mathrm{NAr})\left(\mathrm{C}_{4} \mathrm{H}_{8}\right)\left(\mathrm{OSiPh}_{3}\right)_{2}(\mathbf{1 0})$ (equation 10). When 3 was exposed to ${ }^{13} \mathrm{C}$-ethylene $(\sim 0.5 \mathrm{~atm})$ at $20{ }^{\circ} \mathrm{C}$, two resonances are observed in the ${ }^{13} \mathrm{C}$ NMR spectrum at 72.4 and $37.5 \mathrm{ppm}$ that can be assigned to $\mathrm{C}_{\alpha}$ and $\mathrm{C}_{\beta}$, respectively, along with a resonance for the ${ }^{13} \mathrm{C}$-labeled ethylene complex (at $55.2 \mathrm{ppm}$ ). Although ethylene exchange is facile on the chemical time scale, this exchange is not rapid on the NMR time scale since a small amount of $\mathbf{3}$ can be observed throughout the temperature range shown in Figure 6. It appears that the fluxional process shown in Figure 6 leads to equilibration of the two types of $\mathrm{CH}_{\alpha}$ resonances ("upper" and "lower") and the two types of $\mathrm{CH}_{\beta}$ resonances ("upper" and "lower"), but not to interconversion of $\mathrm{CH}_{\alpha}$ and $\mathrm{CH}_{\beta}$ resonances or equilibration of $\mathbf{1 0}$ with $\mathbf{3}$ on the NMR time scale. Compound $\mathbf{1 0}$ clearly must 


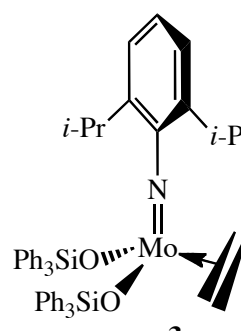

3

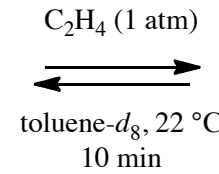

$10 \mathrm{~min}$

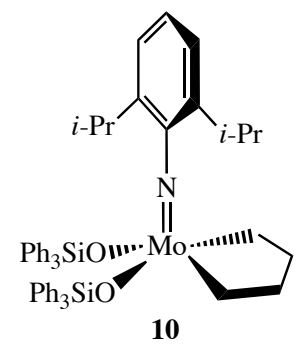

form from an intermediate bis ethylene complex in which the ethylenes are approximately cis to one another, perhaps through rearrangement of an initial species that has some other structure, even an initial TBP species that contains ethylenes trans to one another. The fluxional process observed for $\mathbf{1 0}$ is proposed to consist of a five-coordinate rearrangement of either the intact metallacyclopentane or a $\mathrm{Mo}(\mathrm{VI})$ alkenyl hydride species formed from the metallacyclopentane through reversible $\beta$ hydride elimination. The fact that $\mathrm{CH}_{\alpha}$ and $\mathrm{CH}_{\beta}$ resonances do not exchange eliminates the possibility of formation of a bisethylene species in which one or both ethylenes can rotate about the Mo(ethylene) bond axis. The fluxional process has been investigated by line-shape analyses of the $\beta$-protons (see Supporting Information). The activation parameters for the exchange of the $\beta$ protons were obtained from the Eyring plot: $\Delta H^{\ddagger}=18.0(0.3) \mathrm{kcal} / \mathrm{mol}$ and $\Delta \mathrm{S}^{\ddagger}=15.6(1.2)$ eu. The large and positive entropy of activation is consistent with significant disorder in the transition state, and therefore would favor formation of an alkenyl hydride intermediate.

X-ray quality crystals of $\mathbf{1 0}$ were grown from a pentane:toluene (10:1) solution of $\mathbf{1 0}$ at $\mathbf{- 3 5}$ ${ }^{\circ} \mathrm{C}$ under 1 atm of ethylene. A drawing of the structure of $\mathbf{1 0}$ is shown in Figure 7. Complex $\mathbf{1 0}$ has an approximate square pyramidal coordination geometry, with the imido ligand occupying the apical position. It is similar to the structure of a molybdacyclopentane reported by Boncella. ${ }^{20} \mathrm{The}_{\mathrm{Mo}}(1)$ $\mathrm{C}(1)$ and $\mathrm{Mo}(1)-\mathrm{C}(4)$ bonds (2.176(3) and 2.200(3) $\AA$ ) are typical of Mo-C single bonds and the $\mathrm{C}(1)-\mathrm{C}(2), \mathrm{C}(2)-\mathrm{C}(3)$, and $\mathrm{C}(3)-\mathrm{C}(4)$ bond lengths (1.513(5), 1.526(5), and 1.524(5) $\AA$, respectively) are typical of C-C single bonds.

When a sample of $\mathrm{Mo}(\mathrm{NAr})\left(\mathrm{CHCMe}_{2} \mathrm{Ph}\right)\left(\mathrm{OSiPh}_{3}\right)_{2}{ }^{21}$ in toluene- $d_{8}$ was degassed and exposed to 1 atm of ethylene, four broad peaks were observed at 3.38, 2.86, 2.23, and 1.24 ppm in 
the ratio of 1:1:2:2 (see Supporting Information), consistent with the formation of the square pyramidal molybdacylobutane species, $\mathrm{Mo}(\mathrm{NAr})\left(\mathrm{C}_{3} \mathrm{H}_{6}\right)\left(\mathrm{OSiPh}_{3}\right)_{2}(\mathbf{1 1})$ (equation 11). When $\mathrm{Mo}(\mathrm{NAr})\left(\mathrm{CHCMe}_{2} \mathrm{Ph}\right)\left(\mathrm{OSiPh}_{3}\right)_{2}$ was exposed to ${ }^{13} \mathrm{C}$-ethylene $(\sim 0.5 \mathrm{~atm})$ at $20{ }^{\circ} \mathrm{C}$, two doublet resonances were observed in the ${ }^{13} \mathrm{C}$ NMR spectrum at $37.6 \mathrm{ppm}\left(J_{\mathrm{CC}}=33 \mathrm{~Hz}, J_{\mathrm{CH}}=138 \mathrm{~Hz}\right)$ and $27.8 \mathrm{ppm}\left(J_{\mathrm{CC}}=33 \mathrm{~Hz}, J_{\mathrm{CH}}=132 \mathrm{~Hz}\right)$, corresponding to $\mathrm{C}_{\alpha}$ and $\mathrm{C}_{\beta}$, respectively, in a square

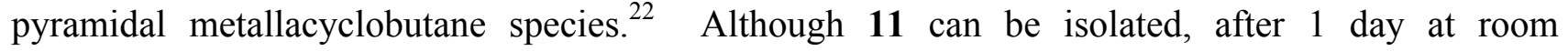
temperature $\mathrm{Mo}(\mathrm{NAr})\left(\mathrm{CH}_{2} \mathrm{CH}_{2}\right)\left(\mathrm{OSiPh}_{3}\right)_{2}(\mathbf{3})$ and $\mathrm{Mo}(\mathrm{NAr})\left(\mathrm{C}_{4} \mathrm{H}_{8}\right)\left(\mathrm{OSiPh}_{3}\right)_{2}(\mathbf{1 0})$ are also found in a solution of 11 as a consequence of decomposition of unobserved $\mathrm{Mo}(\mathrm{NAr})\left(\mathrm{CH}_{2}\right)\left(\mathrm{OSiPh}_{3}\right)_{2}$.
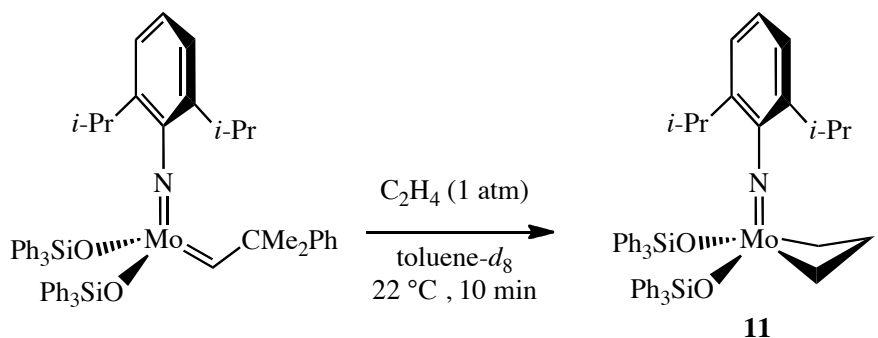

Olefin exchange and double bond isomerization would suggest that linear olefins can be isomerized catalytically. In fact, treatment of $2 \mathrm{c}$ with 20 equivalents of 1 -decene in $\mathrm{C}_{6} \mathrm{D}_{6}(15 \mathrm{mM})$ at room temperature led to resonances near $5.5 \mathrm{ppm}$ characteristic of internal olefins. Upon heating the sample for a period of two days at $85{ }^{\circ} \mathrm{C}$, the 1 -decene was converted almost completely to internal olefins according to ${ }^{1} \mathrm{H}$ NMR spectroscopic studies shown in Figure 8.

When 6 was treated with 20 equiv of 1 -hexene in $\mathrm{C}_{6} \mathrm{D}_{6}$, trace amounts of internal olefins were observed after $20 \mathrm{~min}$ at room temperature. After one day at $22^{\circ} \mathrm{C}$, the sample contained $52 \%$ internal olefins. At $60{ }^{\circ} \mathrm{C}$ over a period of $24 \mathrm{~h}$ the amount of internal olefins increased to $85 \%$ of the mixture, according to NMR spectra similar to those shown in Figure 8. A GC-Mass spectrum of the reaction mixture revealed the presence of $\mathrm{C}_{7} \mathrm{H}_{14}, \mathrm{C}_{8} \mathrm{H}_{16}, \mathrm{C}_{9} \mathrm{H}_{18}, \mathrm{C}_{10} \mathrm{H}_{20}, \mathrm{C}_{11} \mathrm{H}_{22}$, and $\mathrm{C}_{12} \mathrm{H}_{24}$ species. The shorter chains $\left(\mathrm{C}_{7}\right.$ and $\left.\mathrm{C}_{8}\right)$ clearly consist of more than one isomer. When the reaction between 6 and 1-hexene was attempted in diethyl ether under similar conditions, no internal olefins 
were found after one day. This experiment suggests that diethyl ether blocks any reaction that produces internal olefins. When 6 in $\mathrm{C}_{6} \mathrm{D}_{6}$ was treated with trans-3-hexene under similar conditions to those employed for 1-hexene, ${ }^{1} \mathrm{H}$ NMR and GCMS results were analogous to those observed for reactions involving 1-hexene.

When 6 was treated with 20 equiv of 1 -octene, conversion to $90 \%$ internal olefins was observed after heating the reaction mixture to $100{ }^{\circ} \mathrm{C}$ for $18 \mathrm{~h}$. When a similar experiment was carried out in ether, no internal olefins were observed. A GC-Mass spectrum of the internal olefins (Figure 9a) revealed that olefins from $\mathrm{C}_{8} \mathrm{H}_{16}$ to $\mathrm{C}_{20} \mathrm{H}_{40}$ are present, with $\mathrm{C}_{13}$ and $\mathrm{C}_{14}$ being the most abundant; chains longer than $\mathrm{C}_{15}$ constitute a relatively small portion of the mixture. Hydrogenation of the olefins in this mixture $(\mathrm{Pd} / \mathrm{C}$ catalyst; Figure $9 \mathrm{~b})$ converted all olefin isomers to a single linear alkane, which suggests that all internal olefins are linear. A GC-mass spectrum of a standard of linear alkanes $\mathrm{C}_{8} \mathrm{H}_{18}$ to $\mathrm{C}_{14} \mathrm{H}_{30}$ matched the GC-mass spectrum obtained for the hydrogenated mixture in retention time, peak shape, and fragmentation patterns for each alkane.

Mixtures of linear olefins most likely form through metathesis reactions. When 9 was treated with 1 atm of ethylene, the molybdacylopentane species $\mathbf{1 0}$ was observed immediately, along with free trans-3-hexene. After 2 weeks at room temperature, 1-butene was observed in the ${ }^{1} \mathrm{H}$ NMR spectrum of the reaction mixture. When ${ }^{13} \mathrm{C}$-ethylene was employed, a singlet at $113.4 \mathrm{ppm}$ for ${ }^{13} \mathrm{CH}_{2}=\mathrm{CHCH}_{2} \mathrm{CH}_{3}$ was observed in the ${ }^{13} \mathrm{C}$ NMR spectrum of the reaction mixture, consistent with its formation through a metathesis reaction of trans-3-hexene with ${ }^{13} \mathrm{CH}_{2}{ }^{13} \mathrm{CH}_{2}$. After another week at room temperature, ${ }^{13} \mathrm{CH}_{2}=\mathrm{CHCH}_{3}(115.9 \mathrm{ppm}),{ }^{13} \mathrm{CH}_{3} \mathrm{CH}=\mathrm{CHCH}_{3}$ and ${ }^{13} \mathrm{CH}_{2}=\mathrm{CH}^{13} \mathrm{CH}_{3}$ and $18.0 \mathrm{ppm}$ ) were observed in the reaction mixture, all of which are consistent with isomerization of 1-butene to 2-butene, followed by reaction of 2-butene with ${ }^{13} \mathrm{CH}_{2}{ }^{13} \mathrm{CH}_{2}$. All observations are consistent with very slow metathesis of olefins over a period of weeks.

A benzene solution of 6 was placed under 1 atm of $\mathrm{CD}_{3} \mathrm{CH}=\mathrm{CH}_{2}$ and the sample was heated to $60{ }^{\circ} \mathrm{C}$ for 1 day. A ${ }^{2} \mathrm{H}$ NMR spectrum (Figure 10) showed resonances at 4.8 and $5.8 \mathrm{ppm}$, consistent with scrambling of deuterium into all three propylene sites through a process that must 
involve more than reversible $\mathrm{CH}$ or $\mathrm{CD}$ activation of $\mathrm{CD}_{3} \mathrm{CH}=\mathrm{CH}_{2}$ to give allyl intermediates. (See Discussion Section.)

When 6 was treated with 100 equivalents of cyclooctene in $\mathrm{C}_{6} \mathrm{D}_{6}$ polycyclooctene was formed and could be isolated in $38 \%$ yield after $24 \mathrm{~h}$ through precipitation with methanol. The polycyclooctene sample contained $88 \%$ trans double bonds according to ${ }^{13} \mathrm{C}$ NMR spectra.

\section{DISCUSSION}

It is clear from the work reported here that molybdenum ethylene complexes can be the product of "reduction" of the metal upon exposure of MAP species, or bisalkoxides, to ethylene. These results are similar to what has been observed in solution in Mo or $\mathrm{W}$ biphenolate or binaphtholate systems. ${ }^{3,5,4}$ The two most likely mechanisms for formation of ethylene complexes are rearrangement of a molybdacyclobutane complex to an olefin (e.g., rearrangement of the unsubstituted metallacyclobutane to propylene) or bimolecular coupling of methylidene species. Both experimental $^{3 \mathrm{a}}$ and theoretical evidence (for high oxidation state Re, Mo, and $\mathrm{W}$ systems on silica $^{10,23}$ ) suggest that ethylene assists metallacycle rearrangement. Calculations suggest that the mechanism consists of ethylene accepting a $\beta$ hydride from the metallacyclobutane ring and donating it back to an $\alpha$ carbon of the allyl intermediate. Since bis- $\mu$-methylidene species and a bis$\mu$-ethylene species have been structurally characterized in one high oxidation state tungsten system, ${ }^{5}$ formation of the final ethylene complex is likely to involve ethylene attack on the bis- $\mu$-ethylene

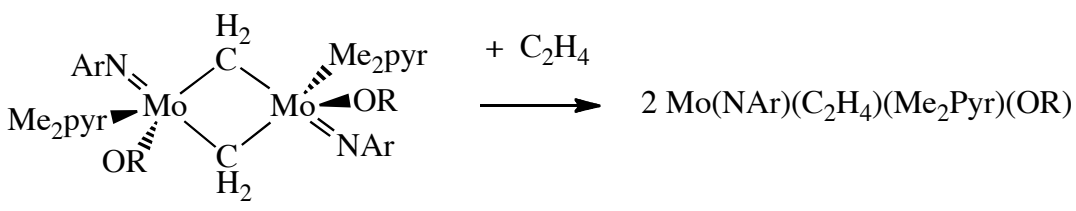

species to give two equivalents of the ethylene species (equation 12) rather than formation of one equivalent of the ethylene species and a high energy three-coordinate intermediate that is then captured by ethylene. Restricting ethylene from the coordination sphere at the point where it is required for the last step (shown in equation 12) could be one of the reasons why MAP methylidene 
species that contain relatively bulky aryloxides are relatively stable toward decomposition reactions and lead to long-lived methylidene complexes and long-lived catalysts in the presence of ethylene. ${ }^{9 \mathrm{~g}}$

Other important findings reported here include facile catalytic isomerization of olefins. We propose that olefins are isomerized via allylic $\mathrm{CH}$ activation to give an allyl intermediate $(\sigma$ or $\pi)$. However, it is not necessarily true that the $\mathrm{H}$ is transferred to the metal, as shown in equation 13 . Another possibility is for $\mathrm{H}$ to be transferred to the imido nitrogen to yield an intermediate $\mathrm{Mo}$ (IV) allyl amido species. However, for the purposes of discussion we will choose the proposal shown in equation 12. This oxidative addition mechanism of isomerizing olefins is one of the classic methods of olefin isomerization that has been documented for decades. ${ }^{24}$

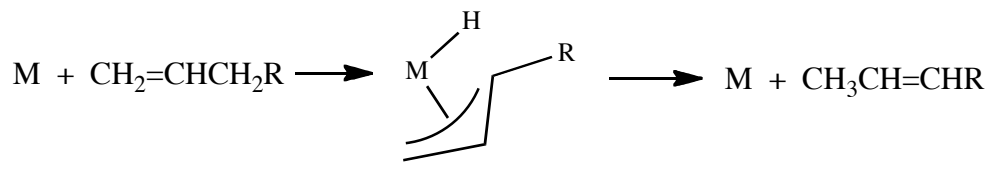

An important question is how an alkylidene, albeit only traces of it, is formed. Some of the leading candidates for forming an alkylidene from an ordinary olefin at a single metal center include addition of $\mathrm{H}$ from an external or internal source (e.g., through $\mathrm{CH}$ activation in a ligand) to the olefin to give an alkyl followed by $\alpha$ abstration of $\mathrm{H}$ from the alkyl, e.g., as shown in equation $14 .^{14,15,16}$ (For convenience, the "+H" and "- $\mathrm{H}$ " nomenclature is meant to encompass reactions that involve $\mathrm{M}-\mathrm{H}$ species and other possible mechanistic variations, e.g., transfer of $\mathrm{H}$ to and from another ligand through $\mathrm{CH}$ activations, etc.) A second possible general mechanism of forming an alkylidene is to form an allyl hydride complex followed by a metallacyclobutane ring; an example is shown in equation 15. Formation of a metallacyclobutane could be an alternative consequence of formation of an olefin isomer from an allyl hydride intermediate (equation 13). The third possibility is to form and contract a metallacyclopentane ring to a metallacyclobutane ring and then lose the olefin to form the alkylidene, e.g., as shown in equation $16^{25,26}$ Unfortunately, we have not been able to think of a means of determining exactly which process is (or processes are) responsible for formation of alkylidenes in the systems reported here, or confirming that they are imido alkylidenes. 

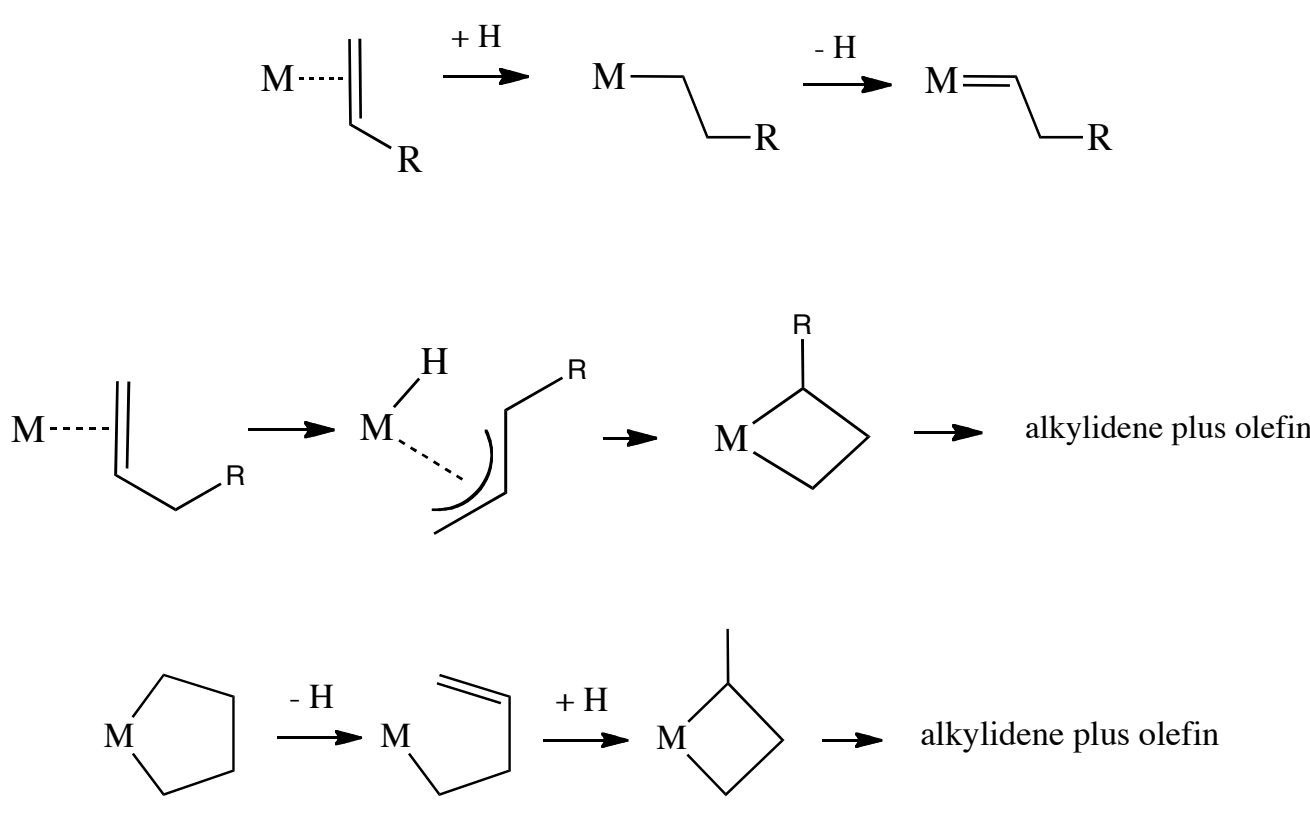

The results presented here are related to others we have uncovered in which Mo(IV) or W(IV) compounds slowly catalyze typical metathesis reactions. As mentioned in the introduction, one is a homologation of a vinyl tin species to an allyl tin species in the presence of ethylene and $\mathrm{Mo}(\mathrm{NAr})\left(\mathrm{CH}_{2} \mathrm{CH}_{2}\right)(\text { Biphen })^{7}$ as a catalyst. A mechanism was proposed that involved contraction of a "mixed" metallacyclopentane ring containing ethylene and the vinyl tin species to a metallacyclobutane ring. Complexes that contain an unsupported $\mathrm{M}=\mathrm{M}$ double bond $(\mathrm{M}=\mathrm{Mo}$ or W) such as $\left[\mathrm{Mo}(\mathrm{NAr})\left(\mathrm{CH}_{2}-t-\mathrm{Bu}\right)\left(\mathrm{OC}_{6} \mathrm{~F}_{5}\right)\right]_{2}\left(\mathrm{Ar}=2,6-i-\mathrm{Pr}_{2} \mathrm{C}_{6} \mathrm{H}_{3}\right)$ or $\left\{\mathrm{W}\left(\mathrm{NAr}^{\prime}\right)\left[\mathrm{OCMe}_{2}\left(\mathrm{CF}_{3}\right)\right]_{2}\right\}_{2}\left(\mathrm{Ar}^{\prime}\right.$ $\left.=2,6-\mathrm{Me}_{2} \mathrm{C}_{6} \mathrm{H}_{3}\right)$ also will slowly catalyze olefin metathesis reactions. ${ }^{8}$ However, it was estimated that only a relatively small amount $(\sim 2 \%)$ of the $M=M$ species was "activated" by the olefin. Finally, an ethylene complex mentioned earlier in this paper, $\mathrm{Mo}\left(\mathrm{N}-2,6-\mathrm{Cl}_{2} \mathrm{C}_{6} \mathrm{H}_{3}\right)\left(\mathrm{CH}_{2} \mathrm{CH}_{2}\right)(\mathrm{rac}$ Biphen)(ether), is inactive for ring-closing of diallyl ether over a period of 10 days at $22{ }^{\circ} \mathrm{C}$, but when 10 equivalents of norbornene were added to a benzene solution of $5 \mathrm{~mol} \%$ $\mathrm{Mo}\left(\mathrm{NAr}{ }^{\mathrm{Cl}}\right)\left(\mathrm{CH}_{2} \mathrm{CH}_{2}\right)(\mathrm{rac}$-Biphen)(ether) and diallyl ether, a 56\% yield of 2,4-dihydrofuran was obtained in 10 days. 
The results reported here also suggest that formation of Mo(IV) species as products of decomposition of metathesis catalysts could lead to isomerization of double bonds in metathesis substrates or products. However, metathesis usually is several orders of magnitude faster than olefin isomerization. Yet there may be some circumstances in which "reformation" of alkylidenes from olefins contributes to catalyst activity over the long term, e.g., "alkane metathesis," which is usually carried out at temperatures of $125^{\circ}$ or more. ${ }^{27}$ Eventually, however, decomposition processes that involve destruction of the basic structure of an imido alkylidene catalyst will lead to irreversible loss of metathesis activity.

\section{CONCLUSIONS}

All of the observations suggest that (i) olefin complexes of the type $\mathrm{M}(\mathrm{NAr})(\mathrm{X})(\mathrm{Y})(\mathrm{olefin})$ can form readily; (ii) exchange of olefins at $\mathrm{Mo}(\mathrm{IV})$ centers is facile; (iii) isomerization of olefins at Mo(IV) centers is facile; and (iv) traces of metathesis catalysts are formed. We propose that the metathesis catalysts are of the type $\mathrm{M}(\mathrm{NAr})(\mathrm{X})(\mathrm{Y})$ (alkylidene), but that the amounts present are in the undetectable range $(<1 \%)$.

\section{Experimental Section}

General synthetic procedures can be found in earlier papers that concern MAP catalysts. ${ }^{9}$ Compounds $\mathbf{1 a}$ and $\mathbf{1 b}$ were prepared as described in the literature. ${ }^{9 \mathrm{a}}$

Mo(NAr)(CHCMe $2 \mathrm{Ph})\left(2,5-\mathrm{Me}_{2} \mathrm{NC}_{4} \mathrm{H}_{2}\right)\left(\mathrm{OSiPh}_{3}\right)$ (1c). A cold solution of $\mathrm{Ph}_{3} \mathrm{SiOH}$ (149 $\mathrm{mg}, 0.54 \mathrm{mmol}, 1$ equiv) in $5 \mathrm{~mL}$ diethyl ether was added dropwise to a cold solution of $\mathrm{Mo}(\mathrm{NAr})\left(\mathrm{CHCMe}_{2} \mathrm{Ph}\right)\left(2,5-\mathrm{Me}_{2} \mathrm{NC}_{4} \mathrm{H}_{2}\right)_{2}(319 \mathrm{mg}, 0.54 \mathrm{mmol}, 1$ equiv) in $5 \mathrm{~mL}$ of diethyl ether. The reaction mixture was stirred at room temperature for 30 minutes and the volatile components were removed in vacuo. The resulting orange solid was recrystallized from diethyl ether to give $259 \mathrm{mg}$ of orange crystals; yield 62\%: ${ }^{1} \mathrm{H}$ NMR $\left(500 \mathrm{MHz}, \mathrm{CD}_{2} \mathrm{Cl}_{2}\right) \delta 11.85\left(\mathrm{~s}, 1 \mathrm{H}\right.$, syn $\mathrm{Mo}=\mathrm{CH}, J_{\mathrm{CH}}=$ 120.4 Hz), 7.54-7.08 (m, 23H, Ar), 5.79 (s, 2H, NC $\left.H_{4} H_{2}\right), 3.72$ (sept, 2H, MeCHMe, J= 7.0 Hz), 2.11 (s, 6H, $\left.\mathrm{CH}_{3}\right), 1.62\left(\mathrm{~s}, 3 \mathrm{H}, \mathrm{CH}_{3}\right), 1.52\left(\mathrm{~s}, 3 \mathrm{H}, \mathrm{CH}_{3}\right), 1.06$ (app d, 6H, MeCHMe), 0.96 (br, 6H, $\mathrm{MeCHMe}) ;{ }^{13} \mathrm{C}$ NMR $\left(125 \mathrm{MHz}, \mathrm{CD}_{2} \mathrm{Cl}_{2}\right) \delta 286.7,153.4,148.6,147.5,136.4,135.7,135.5,130.6$, 
$130.4,128.6,128.4,126.5,126.3,123.5,109.7,108.9,108.1,54.9,31.9,30.6,30.4,29.1,23.8$ (br), 17.3 (br). Anal. Calcd for $\mathrm{C}_{46} \mathrm{H}_{52} \mathrm{MoN}_{2} \mathrm{OSi}$ C, $71.48 ; \mathrm{H}, 6.78 ; \mathrm{N}, 3.62$; Found: $\mathrm{C}, 71.44 ; \mathrm{H}, 6.69 ; \mathrm{N}$, 3.75 .

Mo(NAr) $\left(\mathrm{CH}_{2} \mathrm{CH}_{2}\right)(\mathrm{OAr})\left(2,5-\mathrm{Me}_{2} \mathrm{NC}_{4} \mathrm{H}_{2}\right)$ (2a). A Schlenk flask was charged with $\mathrm{Mo}(\mathrm{NAr})\left(\mathrm{CHCMe}_{2} \mathrm{Ph}\right)(\mathrm{OAr})\left(2,5-\mathrm{Me}_{2} \mathrm{NC}_{4} \mathrm{H}_{2}\right)(60 \mathrm{mg}, 0.090 \mathrm{mmol})$, a stir bar, and $2 \mathrm{~mL}$ of heptane. The solution was degassed by freeze pump thawing the solution ( 3 times) and 1 atm of ethylene was introduced. The reaction was stirred at room temperature for $15 \mathrm{~min}$ and set aside at $-30{ }^{\circ} \mathrm{C}$ for 12 h. Removal of the volatiles in vacuo followed by addition of pentane to the residue afforded a dark red precipitate of the product; yield $31 \mathrm{mg}, 59 \%$ : ${ }^{1} \mathrm{H}$ NMR $\left(300 \mathrm{MHz}, \mathrm{C}_{6} \mathrm{D}_{6}\right) \delta 7.22(\mathrm{~d}, 2, A r), 7.02$ (t, 1, Ar), 6.89 (s, 3, Ar), 5.78 (br, 2, Pyr), 3.57 (sep, 2, CHMe $), 3.25$ (br, 2, CHMe $), 2.95$ (m, 2, ethylene), 2.60 (m, 1, ethylene), 2.16 (s, 6, $\left.\mathrm{Pyr}_{\mathrm{Me}}\right), 1.95$ (m, 1, ethylene), 1.25 - 1.13 (m, 24, CHMe $)$; ${ }^{13} \mathrm{C}$ NMR $\left(125 \mathrm{MHz}, \mathrm{C}_{6} \mathrm{D}_{6}\right) \delta 163.84,155.02,143.74,139.41,128.68,128.40,128.30,127.22$, 123.96, 123.75, 120.77, 107.65, 60.24, 56.29, 28.39, 25.97, 25.18, 24.70, 24.57, 16.02. Experiments employing ${ }^{13} \mathrm{C}_{2} \mathrm{H}_{4}$ revealed the resonances at $60.24 \mathrm{ppm}$ and $56.29 \mathrm{ppm}$ to be those for ethylene carbons $\left(\mathrm{J}_{\mathrm{CH}}=155 \mathrm{~Hz}\right.$ and $\left.\mathrm{J}_{\mathrm{CC}}=39 \mathrm{~Hz}\right)$. Anal. Calcd for $\mathrm{C}_{32} \mathrm{H}_{46} \mathrm{MoN}_{2} \mathrm{O}: \mathrm{C}, 67.35 ; \mathrm{H}, 8.12 ; \mathrm{N}, 4.91$. Found: C, 67.56; H, 8.11; N, 4.97.

$\mathrm{Mo}(\mathrm{NAr})\left(\mathrm{CH}_{2} \mathrm{CH}_{2}\right)\left[\mathrm{OCCMe}\left(\mathrm{CF}_{3}\right)_{2}\right]\left(2,5-\mathrm{Me}_{2} \mathrm{NC}_{4} \mathrm{H}_{2}\right)(2 \mathrm{~b})$. Compound $2 \mathrm{~b}$ was prepared in a manner analogous to 2a by treating $\mathrm{Mo}(\mathrm{NAr})\left(\mathrm{CHCMe}_{3}\right)\left[\mathrm{OCMe}\left(\mathrm{CF}_{3}\right)_{2}\right]\left(2,5-\mathrm{Me}_{2} \mathrm{NC}_{4} \mathrm{H}_{2}\right)(235 \mathrm{mg}$, $0.347 \mathrm{mmol}$ ) with ethylene in heptane. The complex was crystallized from pentane at $-30^{\circ} \mathrm{C}$ as dark red crystals; yield $123 \mathrm{mg}, 57 \%$ : ${ }^{1} \mathrm{H}$ NMR $\left(300 \mathrm{MHz}, \mathrm{C}_{6} \mathrm{D}_{6}\right) \delta 6.19-6.81(\mathrm{~m}, 3, A r), 5.51(\mathrm{br}, 2$, Pyr), 3.48 (sep., 2, $\mathrm{CHMe}_{2}$ ), 2.77 (m, 2, ethylene), 2.45 (m, 1, ethylene), 2.16 (m, 1, ethylene), 2.10 (s, 6, $\left.\mathrm{Pyr}_{M e}\right), 1.65$ (s, 3, OCMe) 1.10 (d, 6, CHMe $), 1.06$ (d, 6, CHMe $)$ ); ${ }^{19} \mathrm{~F}$ NMR (282 MHz, $\left.\mathrm{C}_{6} \mathrm{D}_{6}\right)$ $\delta-75.20,-77.80 ;{ }^{13} \mathrm{C}$ NMR $\left(125 \mathrm{MHz}, \mathrm{C}_{6} \mathrm{D}_{6}\right) \delta 154.24,145.74,128.68,128.27,123.79,110.15$, 105.39, 56.34, 54.12, 28.09, 25.35, 23.62, 20.37, 16.26. Anal. Calcd for $\mathrm{C}_{24} \mathrm{H}_{32} \mathrm{~F}_{6} \mathrm{MoN}_{2} \mathrm{O}: \mathrm{C}, 50.18$; H, 5.61; N, 4.88. Found: C, 50.26; H, 5.31; N, 4.67.

$\mathrm{Mo}(\mathrm{NAr})\left(\mathrm{CH}_{2} \mathrm{CH}_{2}\right)\left(2,5-\mathrm{Me}_{2} \mathrm{NC}_{4} \mathrm{H}_{2}\right)\left(\mathrm{OSiPh}_{3}\right)$ (2c). Compound 2c was prepared in a manner analogous to $2 \mathbf{b}$ by treating $\mathrm{Mo}(\mathrm{NAr})\left(\mathrm{CHCMe}_{2} \mathrm{Ph}\right)\left(2,5-\mathrm{Me}_{2} \mathrm{NC}_{4} \mathrm{H}_{2}\right)\left(\mathrm{OSiPh}_{3}\right)(250 \mathrm{mg}, 0.32$ 
mmol) with ethylene in $5 \mathrm{~mL}$ of diethylether. The dark red precipitate was collected and recrystallized from diethylether; yield $150 \mathrm{mg}, 70 \%$ : ${ }^{1} \mathrm{H}$ NMR $\left(500 \mathrm{MHz}, \mathrm{C}_{6} \mathrm{D}_{6}\right) \delta 7.89(\mathrm{dd}, 6 \mathrm{H}, A r$, $J=7.5 \mathrm{~Hz}, 2.0 \mathrm{~Hz}$ ), 7.24-7.14 (m, 9H, $A r), 6.94-6.83$ (m, 3H, $A r), 5.00-6.00$ (br, $\left.2 \mathrm{H}, \mathrm{NC}_{4} H_{2}\right), 3.71$ (sept, $2 \mathrm{H}, \mathrm{MeCHMe}, J=6.5 \mathrm{~Hz}), 2.87\left(\mathrm{~m}, 1 \mathrm{H}, \mathrm{C}_{2} H_{4}\right), 2.70\left(\mathrm{~m}, 1 \mathrm{H}, \mathrm{C}_{2} H_{4}\right), 2.20\left(\mathrm{~m}, 2 \mathrm{H}, \mathrm{C}_{2} H_{4}\right), 2.11$ (br s, 6H, CH $\left.H_{3}\right), 1.10$ (d, 6H, MeCHMe, $\left.J=7.0 \mathrm{~Hz}\right), 1.00$ (d, 6H, MeCHMe, $J=7.0 \mathrm{~Hz}$ ); ${ }^{13} \mathrm{C} \mathrm{NMR}$ $\left(125 \mathrm{MHz}, \mathrm{C}_{6} \mathrm{D}_{6}\right) \delta 153.8,145.8,141.3,136.3,135.9,129.5,128.7,128.1,127.9,57.9,56.8,28.3$, 25.6, 23.2, 17.0. Experiments employing ${ }^{13} \mathrm{C}_{2} \mathrm{H}_{4}$ revealed ethylene carbon resonances at 56.8 and $57.9 \mathrm{ppm}\left(\mathrm{J}_{\mathrm{CH}}=153 \mathrm{~Hz}\right.$ and $\left.\mathrm{J}_{\mathrm{CC}}=37 \mathrm{~Hz}\right)$. Anal. Calcd for $\mathrm{C}_{38} \mathrm{H}_{44} \mathrm{MoN}_{2} \mathrm{OSi}$ : C, 68.24; H, 6.63; N, 4.19; Found: C, 68.18; H, 6.60; N, 3.84.

Mo(NAr)( $\left.\mathbf{C H}_{2} \mathbf{C H}_{2}\right)\left(\mathbf{O S i P h}_{3}\right)_{2}$ (3). $\mathrm{Mo}(\mathrm{NAr})\left(\mathrm{CH}_{2} \mathrm{CH}_{2}\right)\left(2,5-\mathrm{Me}_{2} \mathrm{NC}_{4} \mathrm{H}_{2}\right)\left(\mathrm{OSiPh}_{3}\right)(25.6 \mathrm{mg}$, $0.038 \mathrm{mmol}, 1$ equiv) and $\mathrm{Ph}_{3} \mathrm{SiOH}(10.6 \mathrm{mg}, 0.038,1$ equiv) were transferred to a $20 \mathrm{~mL}$ vial equipped with a magnetic stir bar. Pentane $(7 \mathrm{~mL})$ and diethyl ether $(0.1 \mathrm{~mL})$ were added. The color of the reaction mixture changed from red to purple. The reaction mixture was stirred at room temperature until triphenylsiloxide was completely consumed. The reaction mixture was stored at $-35{ }^{\circ} \mathrm{C}$ and $20 \mathrm{mg}$ of purple crystals were obtained; yield $=61 \%:{ }^{1} \mathrm{H}$ NMR $\left(500 \mathrm{MHz}, \mathrm{C}_{6} \mathrm{D}_{6}\right) \delta 7.77$ (d, 12H, $A r$ ), 7.20-7.10 (m, 18H, $A r), 6.98-6.89$ (m, 3H, $A r$ ), 3.69 (sept, 2H, MeCHMe, $J=6.9 \mathrm{~Hz}$ ), 2.74 (app q, 2H, $\mathrm{C}_{2} H_{4}, J=6.2 \mathrm{~Hz}, 5.6 \mathrm{~Hz}$ ), 1.99 (app q, 2H, $\mathrm{C}_{2} H_{4}, J=6.2 \mathrm{~Hz}, 5.6 \mathrm{~Hz}$ ), 1.00 (d, $12 \mathrm{H}$, $\left.\mathrm{Me}_{2} \mathrm{CHMe} e_{2}, J=7.0 \mathrm{~Hz}\right) ;{ }^{13} \mathrm{C}$ NMR $\left(125 \mathrm{MHz}, \mathrm{C}_{6} \mathrm{D}_{6}\right) \delta 154.6,146.7,137.6,135.9,130.3,128.5$, 123.4, 55.2, 29.7, 24.0. Experiments employing ${ }^{13} \mathrm{C}_{2} \mathrm{H}_{4}$ revealed the resonance at $55.2 \mathrm{ppm}$ to be that for ethylene carbons $\left(\mathrm{J}_{\mathrm{CH}}=155 \mathrm{~Hz}\right)$. Anal. Calcd for $\mathrm{C}_{50} \mathrm{H}_{51} \mathrm{MoN}_{2} \mathrm{OSi}_{2}: \mathrm{C}, 70.65 ; \mathrm{H}, 6.05 ; \mathrm{N}$, 1.65; Found: C, 70.61; H, 6.14; N, 1.86.

$\operatorname{Mo}(\mathbf{N A r})\left(\mathbf{C H}_{2} \mathbf{C H}_{2}\right)(\mathbf{O T f})_{2}(\mathbf{d m e})$ (4a). Ethylene (60 psi) was added to a solution of $\mathrm{Mo}(\mathrm{NAr})\left(\mathrm{CHCMe}_{2} \mathrm{Ph}\right)(\mathrm{OTf})_{2}(\mathrm{dme})(0.800 \mathrm{~g}, 1.1 \mathrm{mmol})$ in $10 \mathrm{~mL}$ of toluene. The reaction mixture was heated to $80{ }^{\circ} \mathrm{C}$ for two days under a $60 \mathrm{psi}$ of ethylene. Red crystals $(0.646 \mathrm{~g}$, yield $=86 \%)$ were isolated directly from the reaction via filtration. The product is a mixture of cis and trans isomers in the ratio of $\sim 2: 1$, as determined by ${ }^{1} \mathrm{H}$ and ${ }^{19} \mathrm{~F}$ NMR spectroscopy studies: ${ }^{1} \mathrm{H}$ NMR (500 $\left.\mathrm{MHz}, \mathrm{C}_{6} \mathrm{D}_{6}\right)$ cis-4 - selected resonances- $\delta$ 3.93-3.84 (m, $\left.1 \mathrm{H}\right), 3.82-3.73(\mathrm{~m}, 1 \mathrm{H}), 3.53(\mathrm{~s}, 3 \mathrm{H}, \mathrm{OMe})$, 
3.35 (s, 3H, OMe), 1.15 (d, 6H, Me ${ }_{2} \mathrm{CHMe} 2, J=7.0 \mathrm{~Hz}$ ), 0.98 (d, 6H, Me $e_{2} \mathrm{CHMe}, J=7.0 \mathrm{~Hz}$ ); ${ }^{1} \mathrm{H}$ NMR (500 MHz, $\mathrm{C}_{6} \mathrm{D}_{6}$ ) trans-4 - selected resonances- $\delta 3.08$ (s, 3H, OMe), 2.95 (s, 3H, OMe), 1.26 $\left(\mathrm{d}, 12 \mathrm{H}, \mathrm{Me}_{2} \mathrm{CHMe}, J=7.0 \mathrm{~Hz}\right) ;{ }^{13} \mathrm{C}$ NMR $\left(125 \mathrm{MHz}, \mathrm{C}_{6} \mathrm{D}_{6}\right) \delta$ 151.0, 139.4, 124.7, 124.3, 77.4, 72.3, 70.7, 70.2, 69.2, 64.2, 63.1, 28.6, 25.4, 24.9, 23.7; ${ }^{19} \mathrm{~F}\left(282 \mathrm{MHz}, \mathrm{C}_{6} \mathrm{D}_{6}\right) \delta$-78.3, -78.3, -78.6. Anal. Calcd for $\mathrm{C}_{20} \mathrm{H}_{31} \mathrm{~F}_{6} \mathrm{MoNO}_{8} \mathrm{~S}_{2}$ : C, 34.94; H, 4.54; N, 2.04; Found: C, 35.24; H, 4.58; N, 2.06 .

$\operatorname{Mo}(\mathbf{N A d})\left(\mathrm{CH}_{2} \mathbf{C H}_{2}\right)(\mathbf{O T f})_{2}(\mathbf{d m e})(\mathbf{4 b})$. A $100 \mathrm{~mL}$ Schlenk round bottom flask equipped with a side arm and a magnetic stir bar was charged with solid $\mathrm{Mo}(\mathrm{NAd})(\mathrm{OTf})_{2}\left(\mathrm{CH}_{2} \mathrm{CH}_{2}\right)(\mathrm{dme})(354$ $\mathrm{mg}$ ) and $10 \mathrm{~mL}$ benzene. The reaction mixture was degassed (3x) and then exposed to 1 atmosphere of ethylene. The reaction mixture was heated at $60{ }^{\circ} \mathrm{C}$ for $6 \mathrm{~h}$. The volatiles were removed under vacuum and the yellow solid generated was washed with diethyl ether. $155.4 \mathrm{mg}$ of yellow solid were obtained (yield $=71 \%$ ). The product obtained is a mixture of cis and trans isomers in the ratio of $\sim 2: 1$, as determined by ${ }^{1} \mathrm{H}$ and ${ }^{19} \mathrm{~F}$ NMR spectroscopy studies: ${ }^{1} \mathrm{H}$ NMR $\left(500 \mathrm{MHz}, \mathrm{C}_{6} \mathrm{D}_{6}\right)$ 3.95$3.80(\mathrm{~m}), 3.51(\mathrm{~s}, \mathrm{OMe}), 3.47$ (s, OMe), 3.45-3.40 (m), 3.33 (s, OMe), 3.14 (s, OMe), 2.95-2.65 (m),

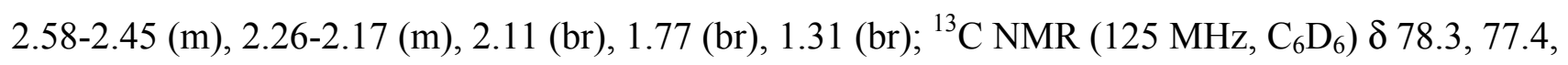
$72.9,72.6,71.7,69.9,69.8,67.6,65.8,64.2,63.0,60.9,41.9,41.1,35.8,35.7,29.4,29.3 ;{ }^{19} \mathrm{~F}(282$ $\left.\mathrm{MHz}, \mathrm{C}_{6} \mathrm{D}_{6}\right) \delta$-77.5, -77.8, -78.3. Anal. Calcd for $\mathrm{C}_{18} \mathrm{H}_{29} \mathrm{~F}_{6} \mathrm{MoNO}_{8} \mathrm{~S}_{2}: \mathrm{C}, 32.68 ; \mathrm{H}, 4.42 ; \mathrm{N}, 2.12$; Found: C, 33.26; H, 4.44; N, 2.00 .

Mo(NAr) $\left(\mathrm{CH}_{2} \mathrm{CH}_{2}\right)\left(\eta^{1}-2,5-\mathrm{Me}_{2} \mathrm{NC}_{4} \mathrm{H}_{2}\right)\left(\eta^{5}-\mathbf{2 , 5}-\mathrm{Me}_{2} \mathrm{NC}_{4} \mathrm{H}_{2}\right)$ (5a). A $25 \mathrm{~mL}$ Schlenk round bottom flask equipped with a side arm and a magnetic stir bar was charged with solid $\mathrm{Mo}(\mathrm{NAr})(\mathrm{OTf})_{2}\left(\mathrm{CH}_{2} \mathrm{CH}_{2}\right)(\mathrm{dme})(156 \mathrm{mg}, 0.23 \mathrm{mmol}, 1$ equiv), and lithium 2,5-dimethylpyrrolide (46 mg, $0.46 \mathrm{mmol}, 2$ equiv). The flask was degassed and $5 \mathrm{~mL}$ of diethyl ether were vacuum transferred into it. The reaction mixture was allowed to warm up and room temperature and then immediately exposed to $1 \mathrm{~atm}$ of ethylene. The mixture was allowed to stir at room temperature for $3 \mathrm{~h}$. The volatile materials were removed under vacuum. Benzene was added and the reaction mixture was filtered through Celite. The volatile materials were removed and the residue was recrystallized from pentane to give $58.3 \mathrm{mg}$ of red crystals; yield $=52 \%:{ }^{1} \mathrm{H}$ NMR (500 MHz, $\mathrm{C}_{6} \mathrm{D}_{6}$ ) $\delta$ 6.90-6.78 (m, 3H, $A r), 6.51$ (s, $\left.2 \mathrm{H}, \mathrm{NC}_{4} H_{2}\right), 5.76\left(\mathrm{~s}, 1 \mathrm{H}, \mathrm{NC}_{4} H_{2}\right), 5.27$ (s, $\left.1 \mathrm{H}, \mathrm{NC}_{4} H_{2}\right), 3.34$ (sept, 
$2 \mathrm{H}, \mathrm{MeCHMe}, J=6.8 \mathrm{~Hz}), 3.06-2.96\left(\mathrm{~m}, 1 \mathrm{H}, \mathrm{C}_{2} H_{4}\right), 2.78-2.68\left(\mathrm{~m}, 1 \mathrm{H}, \mathrm{C}_{2} \mathrm{H}_{4}\right), 2.66-2.56(\mathrm{~m}, 1 \mathrm{H}$, $\left.\mathrm{C}_{2} \mathrm{H}_{4}\right), 2.33-2.23\left(\mathrm{~m}, 1 \mathrm{H}, \mathrm{C}_{2} \mathrm{H}_{4}\right), 2.52\left(\mathrm{~s}, 3 \mathrm{H}, \mathrm{CH}_{3}\right), 2.44\left(\mathrm{~s}, 3 \mathrm{H}, \mathrm{CH}_{3}\right), 1.88\left(\mathrm{~s}, 3 \mathrm{H}, \mathrm{CH}_{3}\right), 1.65(\mathrm{~s}, 3 \mathrm{H}$, $\left.\mathrm{CH}_{3}\right), 1.05(\mathrm{~d}, 6 \mathrm{H}, \mathrm{MeCHMe}, J=6.8 \mathrm{~Hz}), 1.00(\mathrm{~d}, 6 \mathrm{H}, \mathrm{MeCHMe}, J=6.8 \mathrm{~Hz}) ;{ }^{13} \mathrm{C} \mathrm{NMR}(125 \mathrm{MHz}$, $\left.\mathrm{C}_{6} \mathrm{D}_{6}\right) \delta 152.0,151.6,147.9,139.8,139.1,139.6,123.9,112.3,110.9,103.7,100.7,99.4,51.3,48.1$, 28.0, 25.5, 23.3, 21.0, 20.1, 17.2, 14.6. Experiments employing ${ }^{13} \mathrm{C}_{2} \mathrm{H}_{4}$ revealed the resonances at $51.3 \mathrm{ppm}$ and $48.1 \mathrm{ppm}$ to be those for ethylene carbons $\left(\mathrm{J}_{\mathrm{CH}}=157 \mathrm{~Hz}\right.$ for each). Anal. Calcd for $\mathrm{C}_{26} \mathrm{H}_{37} \mathrm{MoN}_{3}$ : C, 64.05; H, 7.65; N, 8.62; Found: C, 63.47; H, 7.52; N, 8.44.

Mo(NAr) $\left(\mathbf{C H}_{2} \mathbf{C H}_{2}\right)\left(2-M e s i t y l N_{4} \mathbf{H}_{3}\right)_{2}(\mathbf{5 b})$. Benzene $(10 \mathrm{~mL})$ was added to a $25 \mathrm{~mL}$ Schlenk flask charged with a stir bar and $\mathrm{Mo}(\mathrm{NAr})\left(\mathrm{CHCMe}_{2} \mathrm{Ph}\right)(\mathrm{MesPyr})_{2}(0.9243 \mathrm{~g}, 1.302 \mathrm{mmol})$. The solution was degassed via three freeze-pump-thaw cycles, and then exposed to 1 atm of ethylene. The closed flask was heated at $60{ }^{\circ} \mathrm{C}$ for 4 days. The volatiles were removed in vacuo to give a brown residue. Pentane $(\sim 5 \mathrm{~mL})$ and $\mathrm{Et}_{2} \mathrm{O}(\sim 1 \mathrm{~mL})$ were added to the residue. The brown solids were collected and dried in vacuo for $1 \mathrm{~h}$; yield $0.620 \mathrm{~g}(71 \%)$ : ${ }^{1} \mathrm{H}$ NMR $\left(500 \mathrm{MHz}, \mathrm{C}_{6} \mathrm{D}_{6}\right) \delta$ 6.88 (m, 3, Ar- $H$, Pyr- $H$ ), 6.82 (s, 1, Ar- $H), 6.81$ (s, 1, Ar- $H), 6.77$ (s, 4, Ar- $H$ ), 6.53 (m, 2, Pyr- $H$ ), 6.24 (m, 2, Pyr- $H$ ), 3.43 (sept, 2, CHMe $), 2.65$ (m, 2, $\left.\mathrm{C}_{2} H_{4}\right), 2.16$ (s, 6, Pyr-Me), 2.11 (s, 12, Pyr$\mathrm{Me}), 1.96\left(\mathrm{~m}, 2, \mathrm{C}_{2} H_{4}\right), 1.00\left(\mathrm{~d}, 12, \mathrm{CHMe} 2, J_{\mathrm{HH}}=7 \mathrm{~Hz}\right) ;{ }^{13} \mathrm{C} \mathrm{NMR}\left(125 \mathrm{MHz}, \mathrm{C}_{6} \mathrm{D}_{6}\right) \delta 154.71$, $147.80,140.50,139.23,138.28,132.46,129.39,129.15,128.96,123.64\left(\mathrm{NC}_{4} \mathrm{H}_{3} \mathrm{Mes}\right), 111.92$ $\left(\mathrm{NC}_{4} \mathrm{H}_{3} \mathrm{Mes}\right), 110.30\left(\mathrm{NC}_{4} \mathrm{H}_{3} \mathrm{Mes}\right), 54.22\left(\mathrm{CH}_{2} \mathrm{CH}_{2}\right), 28.70,24.45,21.95,21.52$. Experiments employing ${ }^{13} \mathrm{C}_{2} \mathrm{H}_{4}$ revealed that the 54.22 resonance is due to ethylene $\left(\mathrm{J}_{\mathrm{CH}}=160 \mathrm{~Hz}\right)$. Anal. Calcd for $\mathrm{C}_{40} \mathrm{H}_{49} \mathrm{MoN}_{3}$ : C, 71.94; H, 7.20; N, 6.29. Found: C, 72.24; H, 7.29; N, 6.05.

$\operatorname{Mo}(\mathrm{NAr})\left(\mathrm{CH}_{2} \mathbf{C H}_{2}\right)\left[\mathbf{O C H}\left(\mathrm{CF}_{3}\right)_{2}\right]_{2}\left(\mathbf{E t}_{\mathbf{2}} \mathrm{O}\right) \quad$ (6). $\mathrm{Mo}(\mathrm{NAr})\left(\mathrm{CH}_{2} \mathrm{CH}_{2}\right)(\mathrm{MesPyr})_{2} \quad(0.201 \mathrm{~g}$, $0.301 \mathrm{mmol}$ ) and $5 \mathrm{~mL}$ of diethyl ether were added to a $20 \mathrm{~mL}$ scintillation vial. Hexafluoroisopropanol (74 $\mu \mathrm{L}, 0.7 .03 \mathrm{mmol}, 2.33$ equiv) was added in portions. The mixture was stirred for $30 \mathrm{~min}$ and filtered through glass wool. The filtrate was concentrated in vacuo to $\sim 1 \mathrm{~mL}$. After standing the solution at $-27{ }^{\circ} \mathrm{C}$ for 1 day red crystals were isolated; yield $0.088 \mathrm{~g}(41 \%):{ }^{1} \mathrm{H}$ NMR (500 MHz, $\left.\mathrm{C}_{6} \mathrm{D}_{6}\right) \delta 6.92(\mathrm{~m}, 3, \mathrm{Ar}-H), 4.68\left(\mathrm{~s}, 2, \mathrm{OCH}_{\left.\left(\mathrm{CF}_{3}\right)_{2}\right),} 3.64\right.$ (q, 4, Et 2 O), 3.54 (sept, 2, $\left.\mathrm{CHMe}_{2}\right), 2.64\left(\mathrm{~m}, 2, \mathrm{C}_{2} \mathrm{H}_{4}\right), 1.83\left(\mathrm{~m}, 2, \mathrm{C}_{2} \mathrm{H}_{4}\right), 1.13\left(\mathrm{~d}, 12, \mathrm{CHMe}{ }_{2}, J_{\mathrm{HH}}=7 \mathrm{~Hz}\right), 0.88\left(\mathrm{t}, 6, E t_{2} O\right)$; 
${ }^{13} \mathrm{C}$ NMR $\left(125 \mathrm{MHz}, \mathrm{C}_{6} \mathrm{D}_{6}\right) \delta 155.05,148.33,129.96,128.58,124.00,78.75\left(\mathrm{CF}_{3}\right), 66.09$ $\left.\left(\mathrm{O}\left(\left(\mathrm{CH}_{2}\right) \mathrm{Me}\right)_{2}\right), 63.17\left(\mathrm{CH}_{2} \mathrm{CH}_{2}\right), 29.14\left(\mathrm{CHMe}_{2}\right), 24.44(\mathrm{CHMe}), 14.26\left(\mathrm{O}_{(}\left(\mathrm{CH}_{2}\right) \mathrm{Me}\right)_{2}\right) ;{ }^{19} \mathrm{~F}$ NMR $\left(282 \mathrm{MHz}, \mathrm{C}_{6} \mathrm{D}_{6}\right) \delta-75.56,-75.88$. Anal. Calcd for $\mathrm{C}_{24} \mathrm{H}_{33} \mathrm{~F}_{12} \mathrm{MoNO}_{3}$ : C, 40.75; H, 4.70; N, 1.98 . Found: C, 40.91; H, 4.67; N, 2.40.

Mo(NAr)(CH $\left.\mathrm{CH}_{2} \mathrm{CHPh}\right)\left(\mathbf{2 , 5}-\mathrm{Me}_{2} \mathrm{NC}_{4} \mathrm{H}_{2}\right)\left(\mathrm{OSiPh}_{3}\right)$ (7). A $25 \mathrm{~mL}$ Schlenk round bottom flask equipped with a side arm and a magnetic stir bar was charged with solid $\mathrm{Mo}(\mathrm{NAr})\left(\mathrm{CH}_{2} \mathrm{CH}_{2}\right)(2,5-$ $\left.\mathrm{Me}_{2} \mathrm{NC}_{4} \mathrm{H}_{2}\right)\left(\mathrm{OSiPh}_{3}\right)$ (306 mg, $\left.0.458 \mathrm{mmol}\right)$. Styrene, freshly dried over $\mathrm{CaH}_{2}$, was vacuum transferred into the Schlenk flask. The reaction mixture was allowed to stir at room temperature for 15 min. The volatiles were removed in vacuo. Pentane $(5 \mathrm{~mL})$ was added and the reaction mixture was placed at $-35{ }^{\circ} \mathrm{C} ; 252 \mathrm{mg}$ of grey solid product was isolated (yield $74 \%$ ): ${ }^{1} \mathrm{H}$ NMR (500 MHz, $\left.\mathrm{C}_{7} \mathrm{D}_{8}\right)$-four isomers; selected peaks- $\delta 4.23\left(\mathrm{t}, 1 \mathrm{H}, \mathrm{CH}_{2}=\mathrm{CHPh}, J=11.5 \mathrm{~Hz}\right), 4.16(\mathrm{t}, 1 \mathrm{H}$, $\left.\mathrm{CH}_{2}=\mathrm{CHPh}, J=11.5 \mathrm{~Hz}\right), 3.80(\mathrm{br}), 3.74-3.20(\mathrm{~m}), 3.08\left(\mathrm{dd}, 1 \mathrm{H}, \mathrm{CH}_{2}=\mathrm{CHPh}, J=11.5,6.5 \mathrm{~Hz}\right)$, $2.97\left(\mathrm{dd}, 1 \mathrm{H}, \mathrm{CH}_{2}=\mathrm{CHPh}, J=11.5,6.0 \mathrm{~Hz}\right.$ ), 2.87-2.79 (m), $2.72\left(\mathrm{dd}, 1 \mathrm{H}, \mathrm{CH}_{2}=\mathrm{CHPh}, J=12.2,6.0\right.$ $\mathrm{Hz}$ ), 2.63-2.56 (m), 2.40 (dd, 1H, $\mathrm{CH}_{2}=\mathrm{CHPh}, J=11.5,6.5 \mathrm{~Hz}$ ), 2.22 (s, Me), 2.09 (s, Me), 1.94 (s, $M e), 1.89$ (br), 1.83 (s, Me), 1.33 (d, 6H, MeCHMe, $J=6.5 \mathrm{~Hz}$ ), 1.17 (d, 6H, MeCHMe, $J=6.5 \mathrm{~Hz}$ ), $1.12(\mathrm{~d}, 6 \mathrm{H}, M e \mathrm{CH} M e, J=6.5 \mathrm{~Hz}), 0.95$ (d, 6H, MeCHMe, $J=6.5 \mathrm{~Hz}$ ), 0.83 (d, 6H, MeCHMe, $J=$ $6.5 \mathrm{~Hz}) ;{ }^{13} \mathrm{C}$ NMR $\left(125 \mathrm{MHz}, \mathrm{C}_{7} \mathrm{D}_{8}\right) \delta 154.6,154.0,151.8,147.0,146.7,146.5,146.1,146.0,141.5$, $141.0,139.8,138.4,136.4,136.3,130.0,129.8,128.9,128.3,128.0,127.0,126.2,124.0,123.8$, 123.6, 113.9, 109.2 (br), 104.1, 76.8, 73.7, 66.8, 60.0, 57.9, 57.7, 56.7, 54.6, 29.1, 28.7, 28.6, 26.2, 25.6, 25.3, 24.1, 23.6, 23.4, 17.4. Anal. Calcd for $\mathrm{C}_{44} \mathrm{H}_{48} \mathrm{MoN}_{2} \mathrm{OSi}$ : C, 70.94; H, 6.49; N, 3.76; Found: C, 70.62; H, 6.67; N, 3.75 .

Mo(NAr)( $\left.\mathrm{CH}_{2} \mathbf{C H P h}\right)\left(\mathrm{OSiPh}_{3}\right)_{2}$ (8). Method A: A $25 \mathrm{~mL}$ Schlenk round bottom flask equipped with a side arm and a magnetic stir bar was charged with solid $\mathrm{Mo}(\mathrm{NAr})\left(\mathrm{CH}_{2} \mathrm{CH}_{2}\right)\left(\mathrm{OSiPh}_{3}\right)_{2}(60 \mathrm{mg}, 0.0706 \mathrm{mmol})$. Styrene, freshly dried over $\mathrm{CaH}_{2}$, was vacuum transferred to the Schlenk flask. The reaction mixture changed immediately from purple to green. The volatiles were then removed in vacuo and after recrystallization from pentane, $64 \mathrm{mg}$ of green crystals were generated (yield $=98 \%$ ). 
Method B: $\mathrm{Mo}(\mathrm{NAr})\left(\mathrm{CH}_{2} \mathrm{CHPh}\right)\left(2,5-\mathrm{Me}_{2} \mathrm{NC}_{4} \mathrm{H}_{2}\right)\left(\mathrm{OSiPh}_{3}\right)(41.5 \mathrm{mg}, 0.056 \mathrm{mmol}, 1$ equiv) and $\mathrm{Ph}_{3} \mathrm{SiOH}$ (15.4 mg, 0.056, 1 equiv) were transferred to a $20 \mathrm{~mL}$ vial equipped with a magnetic stir bar. Pentane $(5 \mathrm{~mL})$ and $0.1 \mathrm{~mL}$ of diethyl ether were added. The color of the reaction mixture changed from red to green. The reaction mixture was stirred at room temperature until the starting material was completely consumed. The reaction mixture was placed at $-35{ }^{\circ} \mathrm{C}$, and $44.1 \mathrm{mg}$ of green crystals were obtained (yield 85\%): ${ }^{1} \mathrm{H}$ NMR (500 MHz, $\left.\mathrm{C}_{6} \mathrm{D}_{6}\right)$-major isomer (67\%)- $\delta 7.79$ $(\mathrm{d}, 6 \mathrm{H}, A r, J=6.5 \mathrm{~Hz}), 7.73(\mathrm{~d}, 6 \mathrm{H}, A r, J=6.5 \mathrm{~Hz}), 7.30-6.60(\mathrm{~m}, 26 \mathrm{H}, A r), 3.58(\mathrm{t}, 1 \mathrm{H}$, $\mathrm{CH}_{2}=\mathrm{C} H \mathrm{Ph}, J=12.3 \mathrm{~Hz}$ ), 3.41 (sept, 2H, MeCHMe, $\left.J=6.8 \mathrm{~Hz}\right), 3.28\left(\mathrm{dd}, 1 \mathrm{H}, \mathrm{CH}_{2}=\mathrm{CHPh}, J=\right.$ 12.3, $6.4 \mathrm{~Hz}$ ), $2.44\left(\mathrm{dd}, 1 \mathrm{H}, \mathrm{CH}_{2}=\mathrm{CHPh}, J=12.3,6.4 \mathrm{~Hz}\right), 0.98(\mathrm{~d}, 6 \mathrm{H}, M e \mathrm{CH} M e, J=6.8 \mathrm{~Hz}), 0.75$ $(\mathrm{d}, 6 \mathrm{H}, M e \mathrm{CHMe}, J=6.8 \mathrm{~Hz})$; -minor isomer $(33 \%)-\delta 7.75(\mathrm{~d}, 6 \mathrm{H}, A r, J=6.5 \mathrm{~Hz}), 7.47(\mathrm{~d}, 6 \mathrm{H}, A r$, $J=6.5 \mathrm{~Hz}), 7.30-6.60(\mathrm{~m}, 26 \mathrm{H}, A r), 4.64\left(\mathrm{t}, 1 \mathrm{H}, \mathrm{CH}_{2}=\mathrm{CHPh}, J=10.9 \mathrm{~Hz}\right), 3.72(\mathrm{sept}, 2 \mathrm{H}$, MeCHMe, $J=6.8 \mathrm{~Hz}), 2.99\left(\mathrm{dd}, 1 \mathrm{H}, \mathrm{CH}_{2}=\mathrm{CHPh}, J=10.9,6.7 \mathrm{~Hz}\right), 2.26\left(\mathrm{dd}, 1 \mathrm{H}, \mathrm{CH}_{2}=\mathrm{CHPh}, J=\right.$ 10.9, $6.7 \mathrm{~Hz}), 1.02$ (d, 6H, MeCHMe, $J=6.8 \mathrm{~Hz}), 0.96(\mathrm{~d}, 6 \mathrm{H}, \mathrm{MeCHMe}, J=6.8 \mathrm{~Hz}) ;{ }^{13} \mathrm{C} \mathrm{NMR}$ $\left(125 \mathrm{MHz}, \mathrm{C}_{6} \mathrm{D}_{6}\right)$-major and minor isomers- $\delta$ 154.8, 154.0, 148.1, 147.1, 145.6, 144.7, 137.7, $137.5,137.5,137.2,136.2,136.1,136.0,135.9,130.5,130.4,130.3,130.0,129.0,128.7,128.6$, $128.5,128.3,128.0,126.8,126.2,125.9,125.7,123.5,123.3,77.0,73.0,54.3,52.1,29.7,29.4,25.1$, 24.7, 23.7, 23.0. Anal. Calcd for $\mathrm{C}_{56} \mathrm{H}_{55} \mathrm{MoO}_{2} \mathrm{Si}_{2}$ : C, 72.62; H, 5.99; N, 1.51; Found: C, 72.71; H, $6.01 ; \mathrm{N}, 1.47$.

Mo(NAr)(trans-3-hexene)(OSiPh $)_{2}$ (9). A 1 dram vial was charged with solid Mo(NAr) $\left(\mathrm{CH}_{2} \mathrm{CH}_{2}\right)\left(\mathrm{OSiPh}_{3}\right)_{2}(96 \mathrm{mg}, 0.113 \mathrm{mmol})$. Addition of neat trans-3-hexene $(100 \mu \mathrm{L})$ led to a color change from purple to indigo. Pentane $(0.1 \mathrm{~mL})$ was added and indigo crystals formed and were filtered off. The crystals were washed with pentane and dried in vacuo; yield $69 \mathrm{mg}$ (67\%): ${ }^{1} \mathrm{H}$ NMR (500 MHz, $\left.\mathrm{C}_{6} \mathrm{D}_{6}\right)$-major isomer 9a (80\%) selected peaks- $\delta 7.79(\mathrm{t}, 12 \mathrm{H}, A r, J=6.7 \mathrm{~Hz})$, 7.26-7.04 (m, 18H, Ar), 7.00-6.88 (m, 3H, Ar), 3.82 (sept, 2H, MeCHMe, J=6.8 Hz), 3.49-3.32 (m, $1 \mathrm{H}), 2.42-2.30(\mathrm{~m}, 1 \mathrm{H}), 2.20-2.03(\mathrm{~m}, 1 \mathrm{H}), 2.03-1.91(\mathrm{~m}, 1 \mathrm{H}), 1.75-1.62(\mathrm{~m}, 1 \mathrm{H}), 1.42-1.32(\mathrm{~m}$, 1H), $1.11(\mathrm{~d}, 6 \mathrm{H}, M e \mathrm{CH} M e, J=6.8 \mathrm{~Hz}), 0.97$ (d, 6H, MeCHMe, $J=6.8 \mathrm{~Hz}), 0.94(\mathrm{t}, 3 \mathrm{H}$, $\left.M e \mathrm{CH}_{2} \mathrm{CH}=, J=7.3 \mathrm{~Hz}\right), 0.89\left(\mathrm{t}, 3 \mathrm{H}, \mathrm{MeCH}_{2} \mathrm{CH}=, J=7.3 \mathrm{~Hz}\right)$; -minor isomer 9b (20\%) selected 
peaks- $\delta 3.75$ (sept, $2 \mathrm{H}, \mathrm{MeCHMe}, J=6.8 \mathrm{~Hz}$ ), $2.68\left(\mathrm{~m}, 2 \mathrm{H}, \mathrm{MeCH}_{2} \mathrm{CH}=\right.$ ), 1.00 (d, 12H, MeCHMe, $J=6.8 \mathrm{~Hz}) ;{ }^{13} \mathrm{C}$ NMR $\left(125 \mathrm{MHz}, \mathrm{C}_{6} \mathrm{D}_{6}\right)$-major and minor isomers- $\delta 153.6,147.3,138.3,137.4$, 136.1, 136.0, 135.8, 130.4, 130.1, 128.7, 128.4, 128.3, 123.5, 78.1, 77.3, 33.8, 29.8, 28.4, 25.4, 23.0, 20.0, 18.6. Anal. Calcd for $\mathrm{C}_{54} \mathrm{H}_{59} \mathrm{MoO}_{2} \mathrm{Si}_{2}: \mathrm{C}, 71.57 ; \mathrm{H}, 6.56 ; \mathrm{N}, 1.55$; Found: C, 71.67; H, 6.65; $\mathrm{N}, 1.59$.

Mo(NAr) $\left(\mathbf{C}_{4} \mathbf{H}_{8}\right)\left(\mathrm{OSiPh}_{3}\right)_{2}$ (10). A J-Young NMR tube was charged with a solution of $\mathrm{Mo}(\mathrm{NAr})\left(\mathrm{CH}_{2} \mathrm{CH}_{2}\right)\left(\mathrm{OSiPh}_{3}\right)_{2}(15 \mathrm{mg})$ in $0.6 \mathrm{~mL}$ of pentane and $0.1 \mathrm{~mL}$ of diethyl ether. The NMR tube was degassed three times and filled with 1 atm of ethylene. After 10 minutes at room temperature, the reaction mixture had changed from purple to red-orange. The NMR tube was stored at $-35^{\circ} \mathrm{C}$ to give orange crystals; $5.0 \mathrm{mg}, 32 \%$ yield. X-ray quality crystals of $\mathbf{1 0}$ were grown from a pentane:toluene solution (10:1) of $\mathbf{1 0}$ at $-35{ }^{\circ} \mathrm{C}$ under 1 atm of ethylene: ${ }^{1} \mathrm{H}$ NMR (500 MHz, $\left.\mathrm{C}_{7} \mathrm{D}_{8},-20^{\circ} \mathrm{C}\right) \delta 7.72(\mathrm{~d}, 12 \mathrm{H}, A r, J=7.3 \mathrm{~Hz}), 7.16(\mathrm{t}, 6 \mathrm{H}, A r, J=7.3 \mathrm{~Hz}), 7.07(\mathrm{t}, 12 \mathrm{H}, A r, J=7.3$ $\mathrm{Hz}$ ), 7.02-6.91 (m, 3H, $A r$ ), 3.85 (sept, 2H, MeCHMe, J=7.0 Hz), 3.11 (br, 2H, $\mathrm{MoCH}_{2}$ ), 3.06 (br, 2H, $\mathrm{MoCH}_{2}$ ), 2.58 (br, 2H, $\mathrm{MoCH}_{2} \mathrm{CH}_{2}$ ), 2.41 (br, 2H, $\mathrm{MoCH}_{2} \mathrm{CH}_{2}$ ), 1.04 (d, 12H, MeCHMe, $J=$ 7.0 Hz). Anal. Calcd for $\mathrm{C}_{52} \mathrm{H}_{55} \mathrm{MoO}_{2} \mathrm{Si}_{2}: \mathrm{C}, 71.12 ; \mathrm{H}, 6.31 ; \mathrm{N}, 1.60$; Found: C, 71.50; H, 6.48; N, 1.40 .

When ${ }^{13} \mathrm{C}_{2} \mathrm{H}_{4}(\sim 0.5 \mathrm{~atm})$ was used the following resonances were observed for the metallacyclopentane carbons; ${ }^{13} \mathrm{C}$ NMR $\left(125 \mathrm{MHz}, \mathrm{C}_{7} \mathrm{D}_{8},-20{ }^{\circ} \mathrm{C}\right) \delta 72.4\left(\mathrm{MoC}_{\alpha}\right), 37.5\left(\mathrm{MoC}_{\alpha} C_{\beta}\right)$.

Mo(NAr) $\left(\mathrm{C}_{3} \mathbf{H}_{6}\right)\left(\mathrm{OSiPh}_{3}\right)_{2}$ (11). A J-Young NMR tube was charged with a suspension of $\mathrm{Mo}(\mathrm{NAr})\left(\mathrm{OSiPh}_{3}\right)_{2}\left(\mathrm{CHCMe}_{2} \mathrm{Ph}\right)^{21}(9 \mathrm{mg})$ in $0.6 \mathrm{~mL}$ of pentane. The suspension was degassed $(3 \mathrm{x})$ and then exposed to $1 \mathrm{~atm}$ of ethylene. The reaction mixture was placed at $-35^{\circ} \mathrm{C}$. Red crystals $(5.3$ $\mathrm{mg}$ ) were generated (yield $=65 \%) .{ }^{1} \mathrm{H}$ NMR $\left(500 \mathrm{MHz}, \mathrm{C}_{7} \mathrm{D}_{8}\right)$-selected peaks- $\delta 3.73$ (sept, $2 \mathrm{H}$, $\mathrm{MeC} H \mathrm{Me}, J=6.8 \mathrm{~Hz}$ ), $3.38(\mathrm{br}, 1 \mathrm{H}, \mathrm{MoCH}), 2.86(\mathrm{br}, 1 \mathrm{H}, \mathrm{MoCH}), 2.23\left(\mathrm{br}, 2 \mathrm{H}, \mathrm{MoCH}_{2}\right), 1.24(\mathrm{br}$, $\left.2 \mathrm{H}, \mathrm{MoCH}_{2} \mathrm{CH}_{2}\right), 1.00$ (d, $\left.12 \mathrm{H}, \mathrm{MeCHMe}, J=6.8 \mathrm{~Hz}\right)$; When ${ }^{13} \mathrm{C}_{2} \mathrm{H}_{4}(\sim 0.5 \mathrm{~atm})$ was used the following peaks were observed corresponding to the square-pyramidal molybdacyclobutane carbons; ${ }^{13} \mathrm{C}$ NMR $\left(125 \mathrm{MHz}, \mathrm{C}_{7} \mathrm{D}_{8}\right) \delta 37.6\left(\mathrm{~d}, J_{\mathrm{CC}}=33 \mathrm{~Hz}, J_{\mathrm{CH}}=138 \mathrm{~Hz}, \mathrm{Mo} C_{\alpha}\right), 27.8\left(\mathrm{~d}, J_{\mathrm{CC}}=33 \mathrm{~Hz}, J_{\mathrm{CH}}\right.$ 
$\left.=132 \mathrm{~Hz}, \mathrm{MoC}_{\alpha} C_{\beta}\right)$. Anal. Calcd for $\mathrm{C}_{51} \mathrm{H}_{53} \mathrm{MoO}_{2} \mathrm{Si}_{2}: \mathrm{C}, 70.89 ; \mathrm{H}, 6.18 ; \mathrm{N}, 1.62 ;$ Found: $\mathrm{C}, 71.30$; $\mathrm{H}, 6.48 ; \mathrm{N}, 1.40$.

Reaction involving cyclooctene. To a benzene- $d_{6} \quad\left(\begin{array}{lll}0.6 & \mathrm{~mL}) & \text { solution of }\end{array}\right.$ $\mathrm{Mo}(\mathrm{NAr})\left(\mathrm{CH}_{2} \mathrm{CH}_{2}\right)\left(\mathrm{O}-\mathrm{i}-\mathrm{Pr}_{\mathrm{F} 6}\right)_{2}\left(\mathrm{Et}_{2} \mathrm{O}\right)(0.014 \mathrm{~g}, 0.0198 \mathrm{mmol})$ was added $(260 \mu \mathrm{L}, 1.98 \mathrm{mmol})$ of cyclooctene via syringe. After $24 \mathrm{~h}$ at $23{ }^{\circ} \mathrm{C}$, the mixture was dissolved in methylene chloride, and the solution was then added dropwise to methanol with vigorous stirring. A white precipitate of polycyclooctene was filtered off from the methanol solution; yield $0.082 \mathrm{~g} \mathrm{(38 \% ).} \mathrm{Both} \mathrm{trans} \mathrm{(88 \% )}$ and $c i s(12 \%) \mathrm{CH}=\mathrm{CH}$ bonds were observed: ${ }^{1} \mathrm{H}$ NMR $\left(500 \mathrm{MHz}, \mathrm{CDCl}_{3}\right) \delta 5.38(\mathrm{~m}, 1$, trans- $\mathrm{CH})$, 5.36 (m, 1, cis- $\mathrm{CH}$ ), 2.01 (m, 2, trans- $\mathrm{CH}_{2}$ ), 1.97 (m, 2, cis- $\mathrm{CH}_{2}$ ), 1.31 (br m, 4, trans- $\mathrm{CH}_{2}$ ), 1.29 (m, 2, cis- $\left.\mathrm{CH}_{2}\right) ;{ }^{13} \mathrm{C}$ NMR $\left(125 \mathrm{MHz}, \mathrm{CDCl}_{3}\right) \delta 130.54$ (m, trans- $\mathrm{CH}$ ), 130.08 (m, cis-CH), 32.83 (has a shoulder, trans- and cis- $\left.\mathrm{CH}_{2}\right), 29.96\left(\right.$ cis- $\left.\mathrm{CH}_{2}\right), 29.85$ (trans- $\left.\mathrm{CH}_{2}\right), 29.40\left(\right.$ cis- $\left.\mathrm{CH}_{2}\right), 29.26$ (trans$\mathrm{CH}_{2}$ ).

Crystal Structure Determinations. All structures were solved by direct methods using SHELXS $^{28}$ and refined against F2 on all data by full-matrix least squares with SHELXL-97 $7^{29}$ using established refinement techniques. ${ }^{30}$ For details see Supporting Information.

Acknowledgment. We thank the National Science Foundation for research support (CHE0841187 to R. R. S.) and for departmental X-ray diffraction instrumentation (CHE-0946721).

Supporting Information Available. Experimental details for all NMR experiments and Xray structural studies. Supporting Information is available free of charge via the Internet at http://pubs.acs.org. 


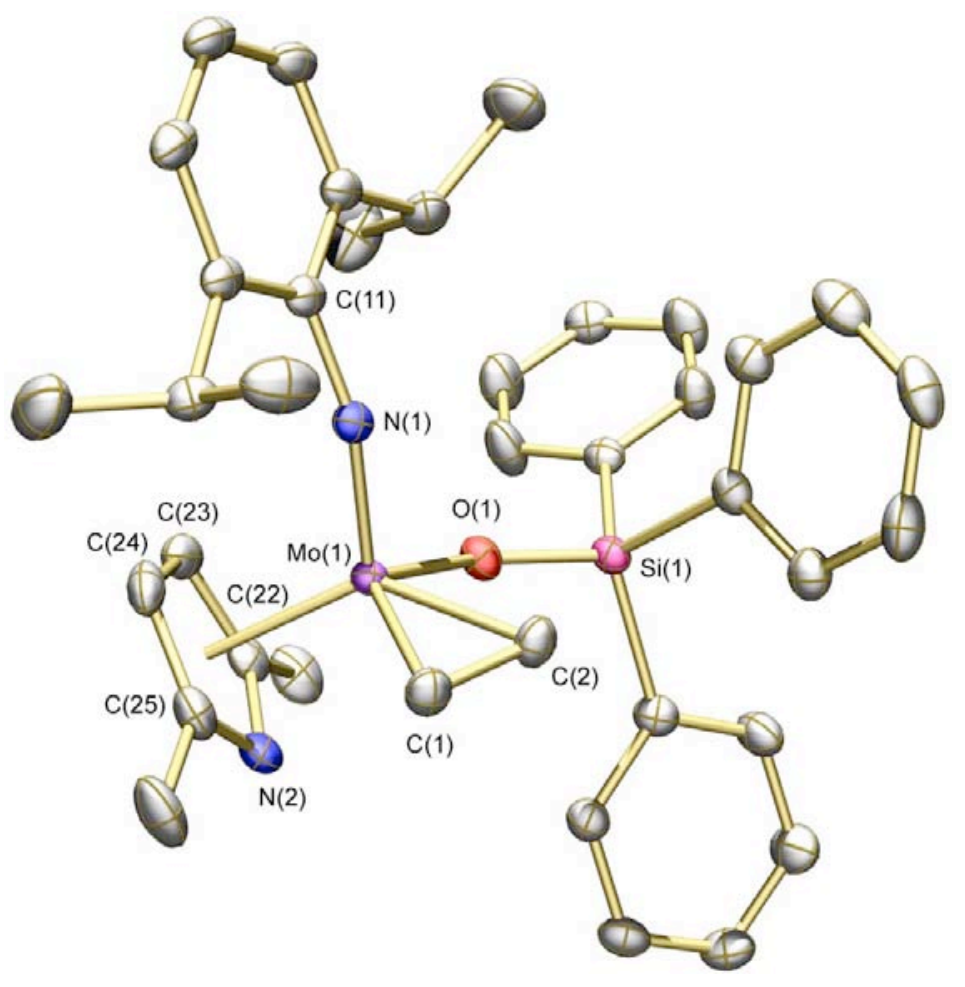

Figure 1. POV-ray drawing of 2c. Thermal ellipsoids are displayed at 50\% probability level. Hydrogen atoms are omitted. Selected distances $(\AA)$ and angles $(\operatorname{deg})$ : $\operatorname{Mo}(1)-C(1)=2.190(2) \AA$, $\operatorname{Mo}(1)-\mathrm{C}(2)=2.182(2) \AA, \operatorname{Mo}(1)-\mathrm{N}(1)=1.7353(18) \AA, \mathrm{Mo}(1)-\mathrm{O}(1)=2.0080(15) \AA, \mathrm{C}(1)-\mathrm{C}(2)=$ 1.420(3) $\AA, \operatorname{Mo}(1)-\mathrm{N}(2)=2.3588(18) \AA, \operatorname{Mo}(1)-\mathrm{C}(22)=2.458(2) \AA, \operatorname{Mo}(1)-\mathrm{C}(23)=2.506(2) \AA$, $\operatorname{Mo}(1)-\mathrm{C}(24)=2.441(2) \AA, \operatorname{Mo}(1)-\mathrm{C}(25)=2.355(2) \AA, \operatorname{Mo}(1)-\mathrm{N}(1)-\mathrm{C}(11)=163.09(15)^{\circ}, \operatorname{Mo}(1)-$ $\mathrm{O}(1)-\mathrm{Si}(1)=149.06(9)^{\circ}, \mathrm{N}(1)-\mathrm{Mo}(1)-\mathrm{C}(1)=98.75(9)^{\circ}, \mathrm{N}(1)-\mathrm{Mo}(1)-\mathrm{C}(2)=97.89(8)^{\circ}$. 


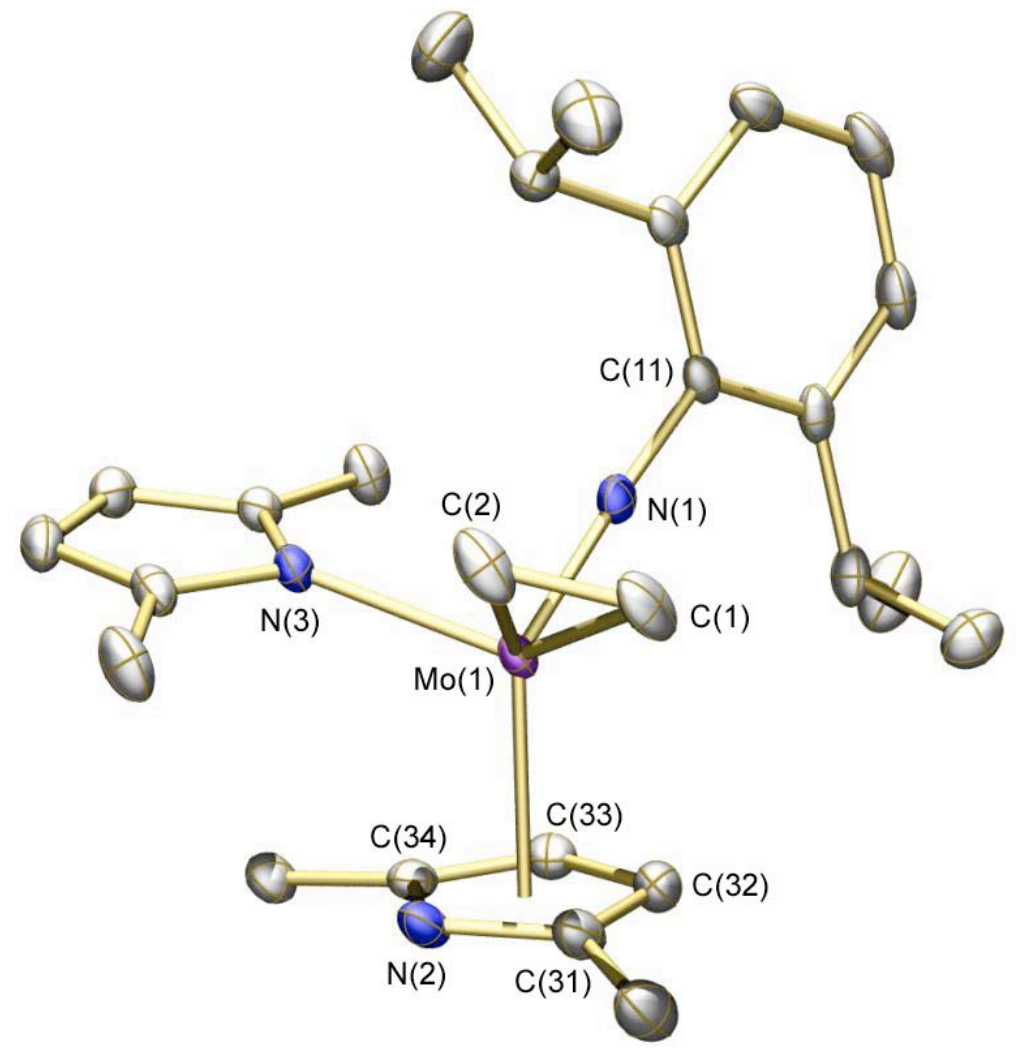

Figure 2. POV-ray drawing of 5a. Thermal ellipsoids are displayed at 50\% probability level. Hydrogen atoms are omitted. Selected distances $(\AA)$ and angles $(\operatorname{deg})$ : $\operatorname{Mo}(1)-C(1)=2.215(2) \AA$, $\operatorname{Mo}(1)-\mathrm{C}(2)=2.199(2) \AA, \operatorname{Mo}(1)-\mathrm{N}(1)=1.7423(17) \AA, \operatorname{Mo}(1)-\mathrm{N}(2)=2.3785(17) \AA, \operatorname{Mo}(1)-\mathrm{N}(3)=$ 2.1444(17) $\AA, \mathrm{C}(1)-\mathrm{C}(2)=1.404(4) \AA, \mathrm{Mo}(1)-\mathrm{C}(31)=2.396(2) \AA, \mathrm{Mo}(1)-\mathrm{C}(32)=2.407(2) \AA$, $\operatorname{Mo}(1)-\mathrm{C}(33)=2.420(2) \AA, \operatorname{Mo}(1)-\mathrm{C}(34)=2.396(2) \AA ̊, \operatorname{Mo}(1)-\mathrm{N}(1)-\mathrm{C}(11)=174.88(14)^{\circ}, \mathrm{N}(1)-$ $\operatorname{Mo}(1)-\mathrm{C}(1)=87.32(8)^{\circ}, \mathrm{N}(1)-\mathrm{Mo}(1)-\mathrm{C}(2)=101.17(8)^{\circ}$. 


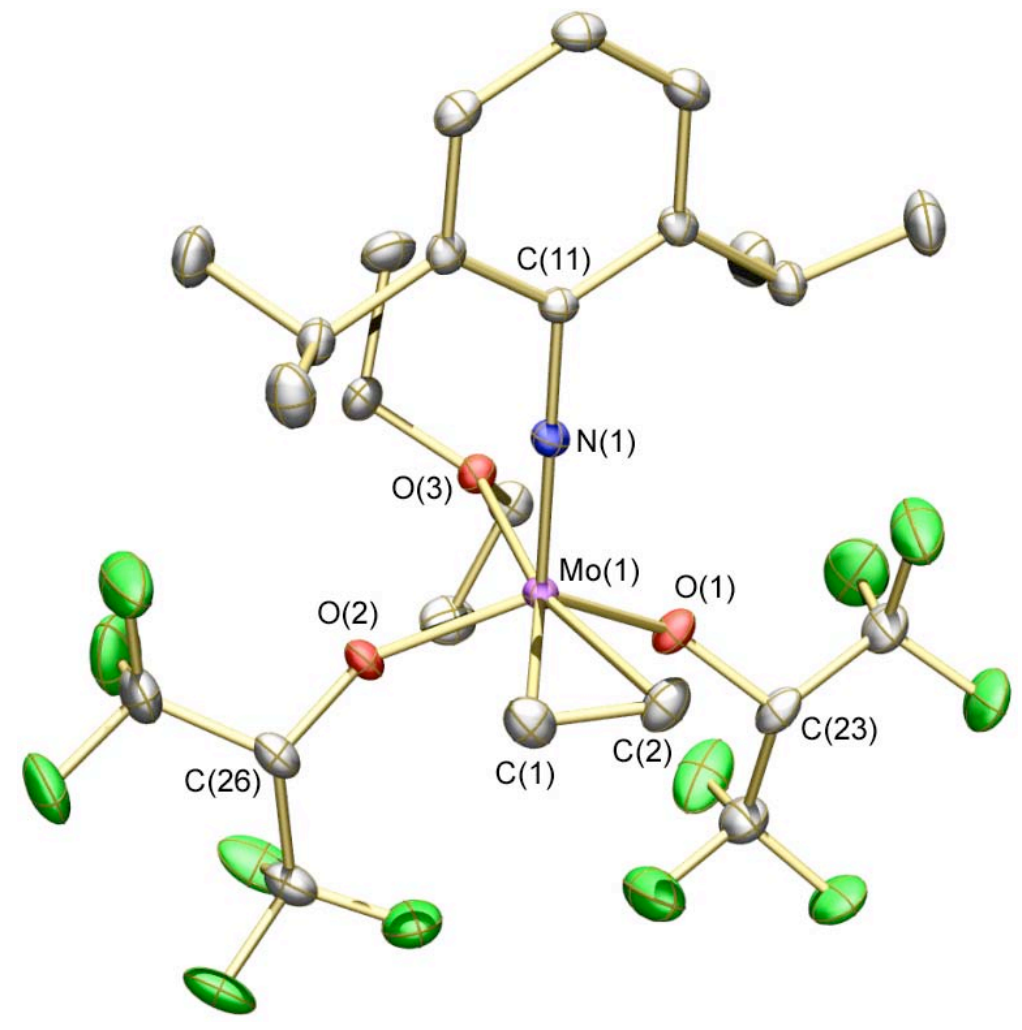

Figure 3. POV-ray drawing of 6. Thermal ellipsoids are displayed at 50\% probability level. Hydrogen atoms are omitted. Selected distances $(\AA)$ and angles (deg): $\operatorname{Mo}(1)-C(1)=2.181(2) \AA$, $\mathrm{Mo}(1)-\mathrm{C}(2)=2.178(2) \AA, \mathrm{C}(1)-\mathrm{C}(2)=1.409(3) \AA, \mathrm{Mo}(1)-\mathrm{O}(1)=1.9792(14) \AA, \mathrm{Mo}(1)-\mathrm{O}(2)=$ $1.9888(14) \AA, \operatorname{Mo}(1)-\mathrm{O}(3)=2.3071(14) \AA, \operatorname{Mo}(1)-\mathrm{N}(1)=1.7148(16) \AA, \operatorname{Mo}(1)-\mathrm{N}(1)-\mathrm{C}(11)=$ $178.18(14)^{\circ}, \mathrm{Mo}(1)-\mathrm{O}(1)-\mathrm{C}(23)=138.89(13)^{\circ}, \mathrm{Mo}(1)-\mathrm{O}(2)-\mathrm{C}(26)=137.50(13)^{\circ}, \mathrm{O}(1)-\mathrm{Mo}(1)-\mathrm{O}(2)$ $=118.18(6)^{\circ}, \mathrm{O}(1)-\mathrm{Mo}(1)-\mathrm{N}(1)=117.77(7)^{\circ}, \mathrm{N}(1)-\mathrm{Mo}(1)-\mathrm{O}(2)=115.60(7)^{\circ}$. 


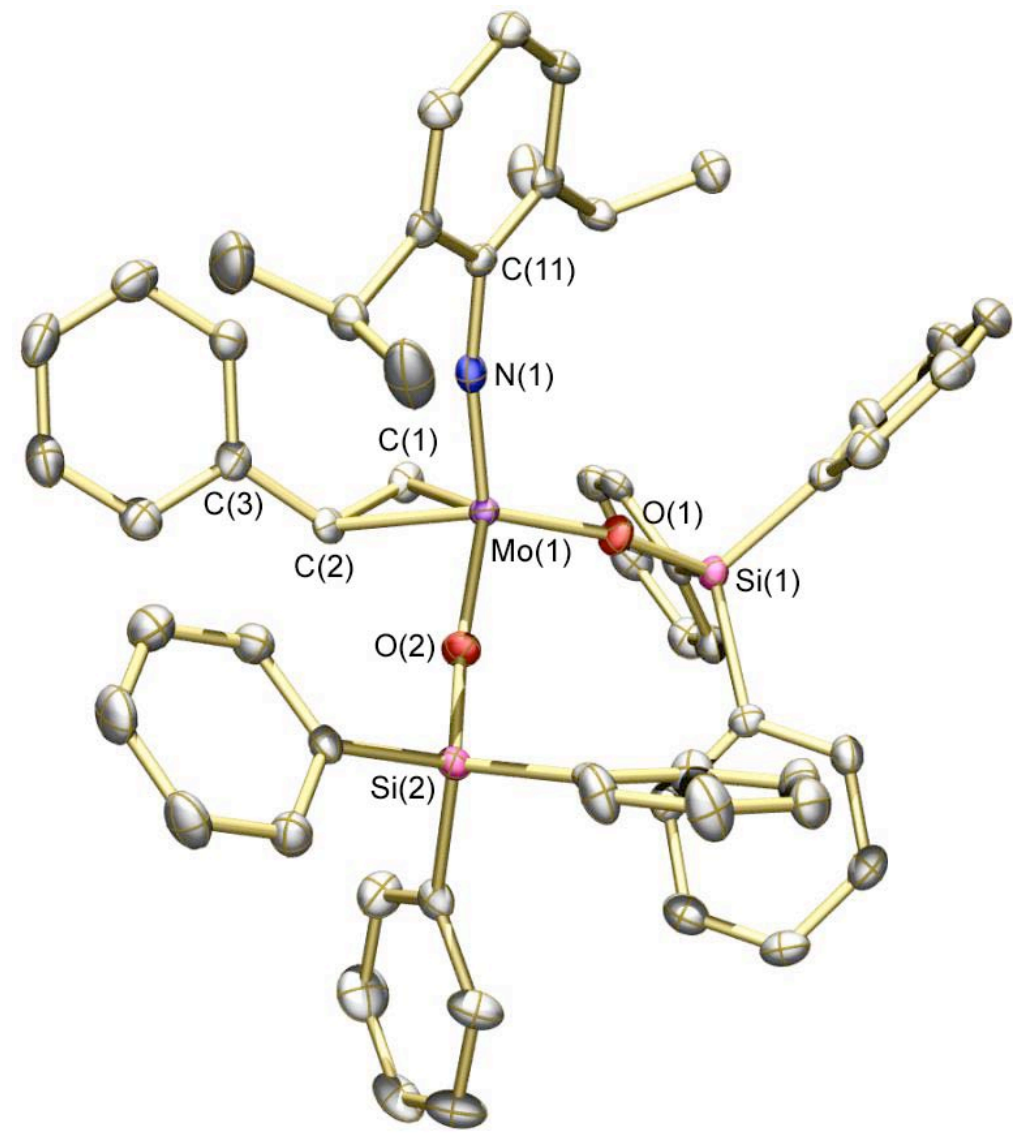

Figure 4. POV-ray drawing of $\mathbf{8}$. Thermal ellipsoids are displayed at $50 \%$ probability level. Hydrogen atoms are omitted. Selected distances $(\AA)$ and angles $(\operatorname{deg}): \operatorname{Mo}(1)-\mathrm{N}(1)=1.738(2) \AA$, $\operatorname{Mo}(1)-\mathrm{O}(1)=1.9116(15) \AA, \operatorname{Mo}(1)-\mathrm{O}(2)=1.9176(16) \AA, \operatorname{Mo}(1)-\mathrm{C}(1)=2.121(3) \AA, \operatorname{Mo}(1)-\mathrm{C}(2)=$ $2.159(2) \AA, \mathrm{C}(1)-\mathrm{C}(2)=1.433(4) \AA, \mathrm{Mo}(1)-\mathrm{N}(1)-\mathrm{C}(11)=169.78(17)^{\circ}, \mathrm{N}(1)-\mathrm{Mo}(1)-\mathrm{C}(1)=$ $98.49(10)^{\circ}, \mathrm{N}(1)-\mathrm{Mo}(1)-\mathrm{C}(2)=98.76(9)^{\circ}$. 


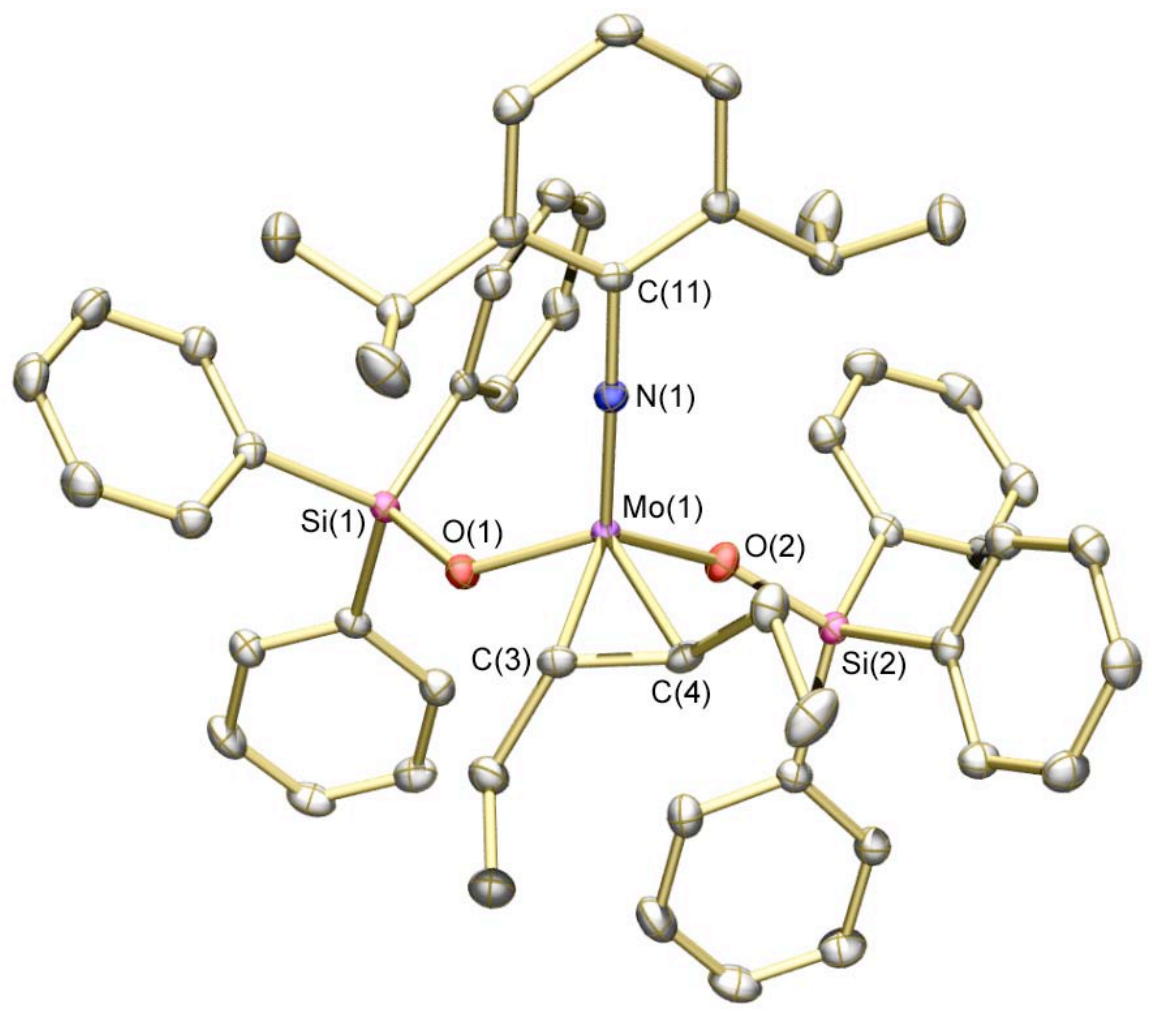

Figure 5. POV-ray drawing of 9a. Thermal ellipsoids are displayed at 50\% probability level. Hydrogen atoms are omitted. Selected distances $(\AA)$ and angles (deg): Mo(1)-N(1) = 1.7337(13) $\AA$, $\mathrm{Mo}(1)-\mathrm{O}(1)=1.9381(11) \AA, \mathrm{Mo}(1)-\mathrm{O}(2)=1.9197(11) \AA, \operatorname{Mo}(1)-\mathrm{C}(3)=2.1509(15) \AA, \operatorname{Mo}(1)-\mathrm{C}(4)$ $=2.1350(15) \AA, \mathrm{C}(3)-\mathrm{C}(4)=1.440(2) \AA, \mathrm{Mo}(1)-\mathrm{N}(1)-\mathrm{C}(11)=174.15(11)^{\circ}, \mathrm{N}(1)-\mathrm{Mo}(1)-\mathrm{C}(3)=$ $98.17(6)^{\circ}, \mathrm{N}(1)-\mathrm{Mo}(1)-\mathrm{C}(4)=97.88(6)^{\circ}$. 


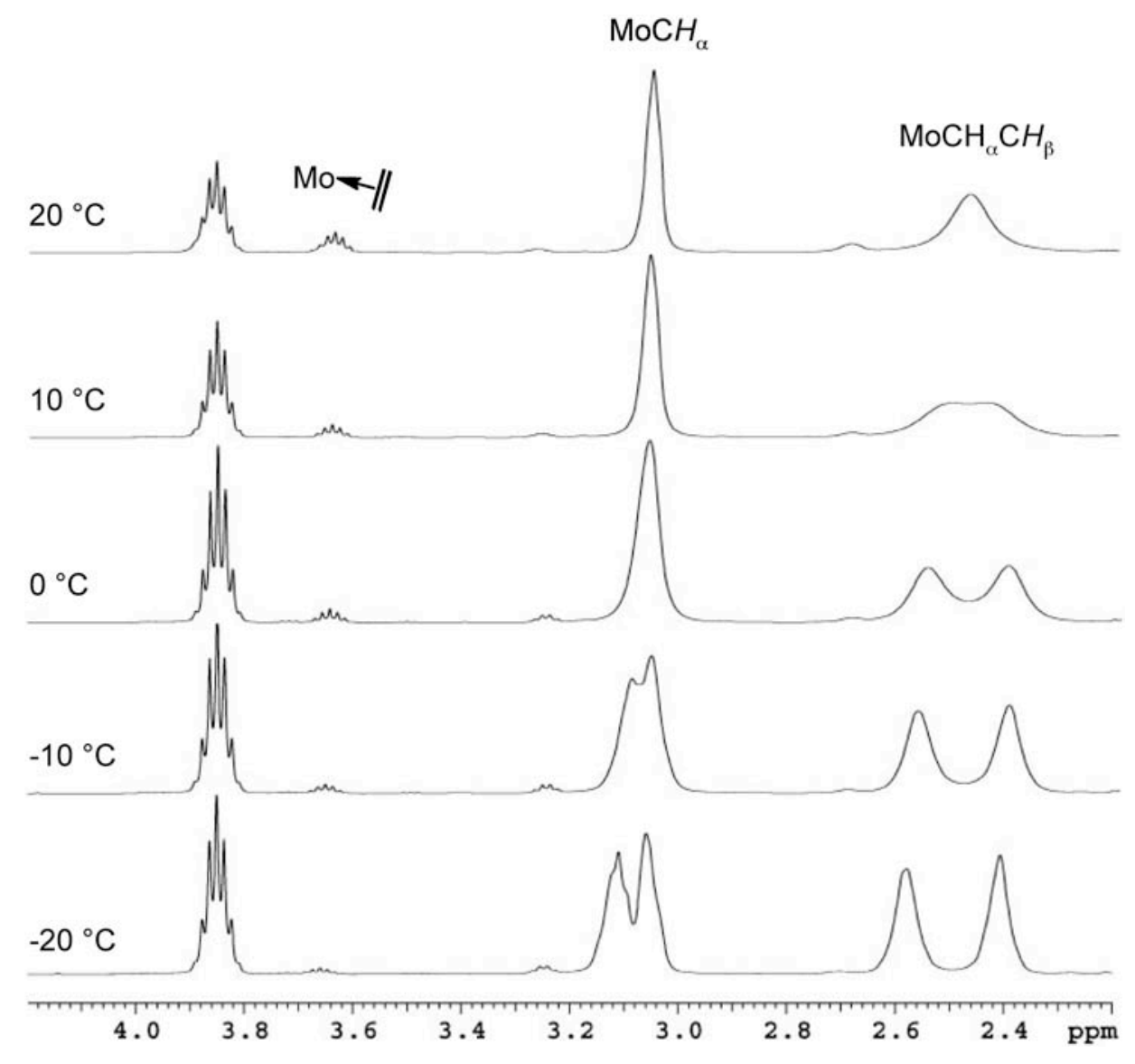

Figure 6. Variable-temperature ${ }^{1} \mathrm{H}$ NMR spectroscopic studies of $\mathrm{Mo}(\mathrm{NAr})\left(\mathrm{OSiPh}_{3}\right)_{2}\left(\mathrm{C}_{4} \mathrm{H}_{8}\right)(\mathbf{1 0})$ in toluene- $d_{8}$ under $1 \mathrm{~atm}$ of ethylene. 


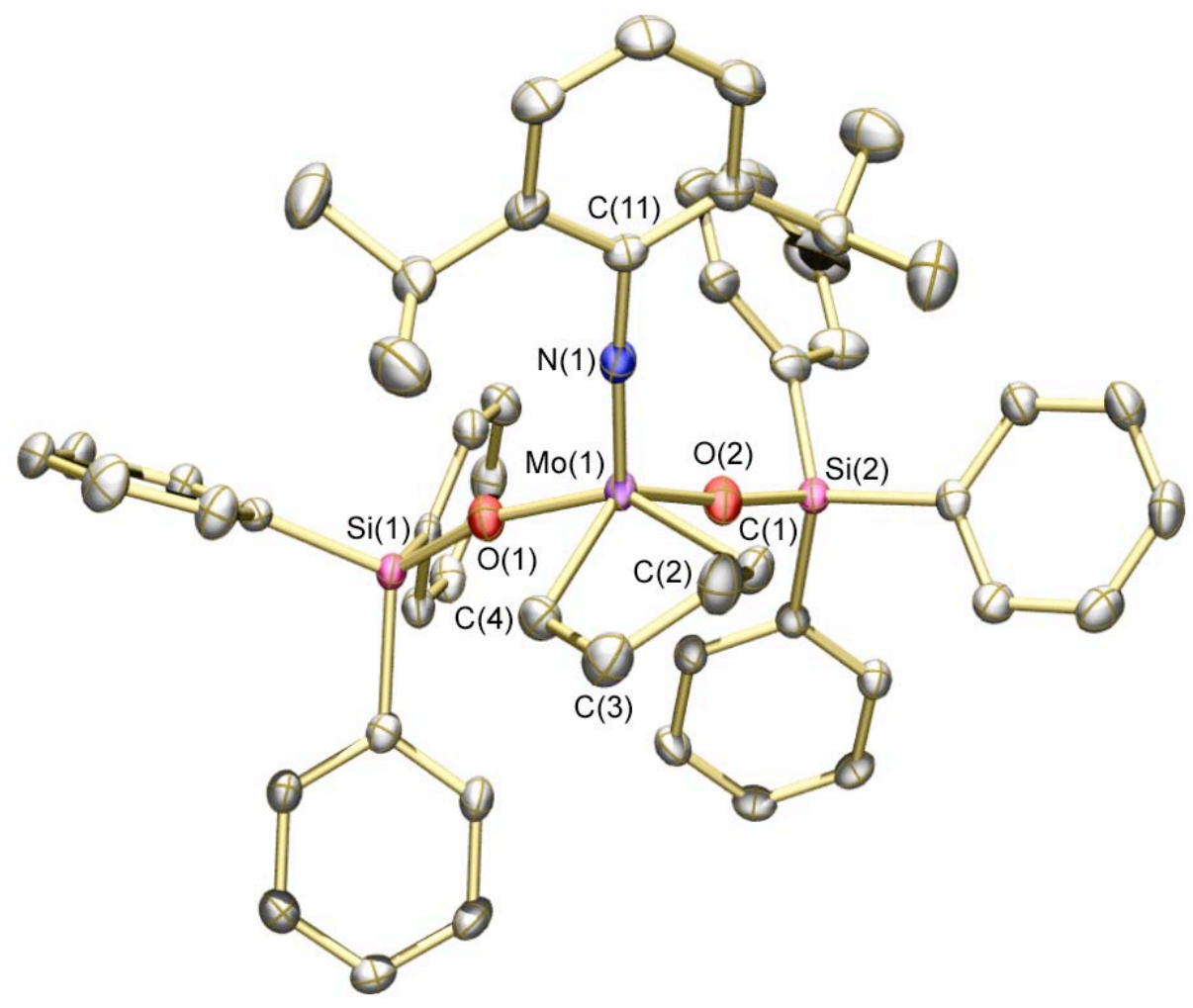

Figure 7. POV-ray drawing of 10. Thermal ellipsoids are displayed at 50\% probability level. Hydrogen atoms are omitted. Selected distances $(\AA)$ and angles (deg): Mo(1)-N(1) = 1.719(2) $\AA$, $\mathrm{Mo}(1)-\mathrm{O}(1)=1.911(2) \AA, \mathrm{Mo}(1)-\mathrm{O}(2)=1.880(2) \AA, \mathrm{Mo}(1)-\mathrm{C}(1)=2.176(3) \AA, \mathrm{Mo}(1)-\mathrm{C}(4)=$ $2.200(3) \AA, \mathrm{C}(1)-\mathrm{C}(2)=1.513(5) \AA, \mathrm{C}(2)-\mathrm{C}(3)=1.526(5) \AA, \mathrm{C}(3)-\mathrm{C}(4)=1.524(5) \AA, \mathrm{Mo}(1)-\mathrm{N}(1)-$ $\mathrm{C}(11)=175.2(2)^{\circ}, \mathrm{C}(1)-\mathrm{Mo}(1)-\mathrm{C}(4)=71.86(13)^{\circ}$. 


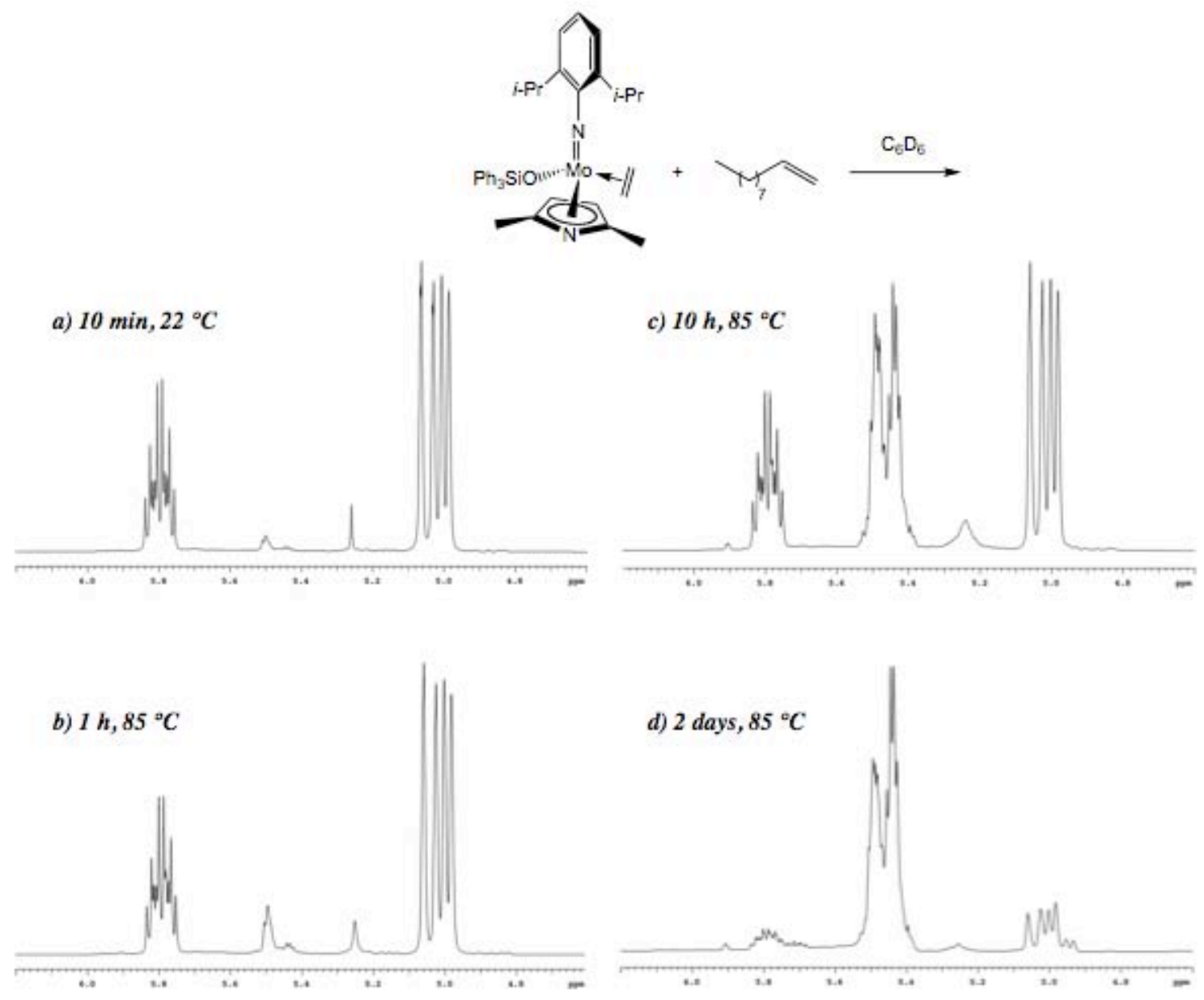

Figure 8. ${ }^{1} \mathrm{H} \quad \mathrm{NMR}$ spectroscopic studies to monitor the reaction between $\mathrm{Mo}(\mathrm{NAr})\left(\mathrm{CH}_{2} \mathrm{CH}_{2}\right)\left(\mathrm{Me}_{2} \mathrm{Pyr}\right)\left(\mathrm{OSiPh}_{3}\right)(\mathbf{2 c})(5 \mathrm{~mol} \%)$ and 1-decene. 
(a)

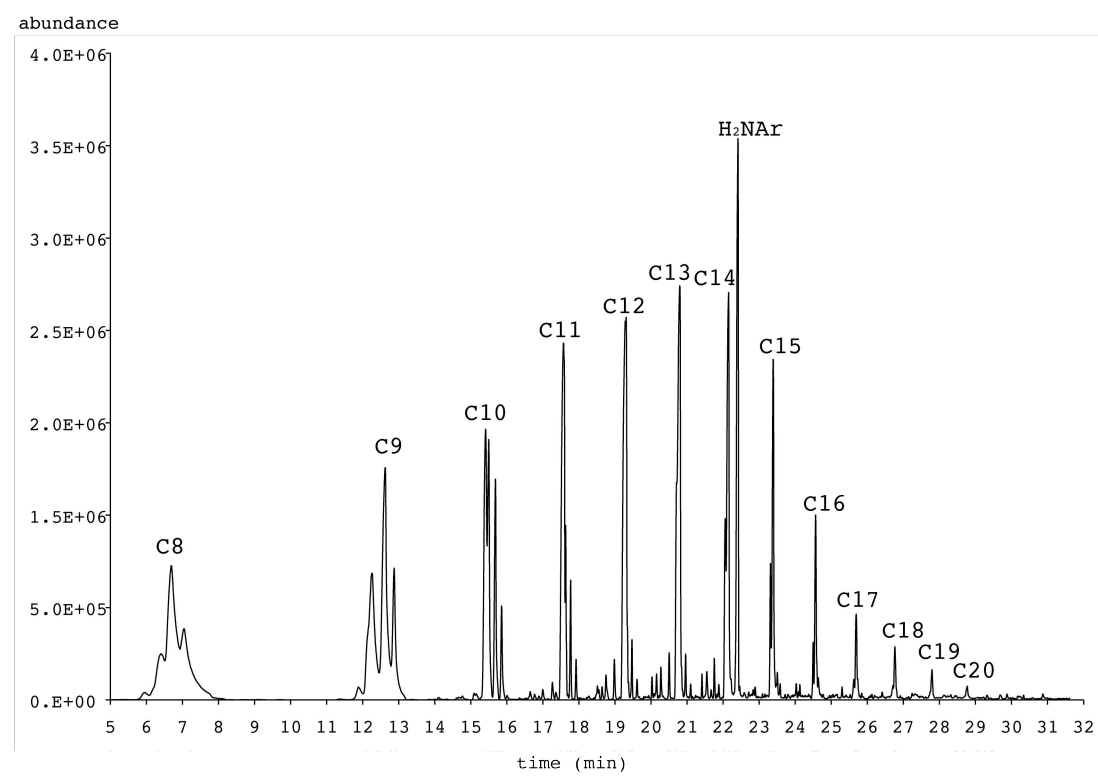

(b)

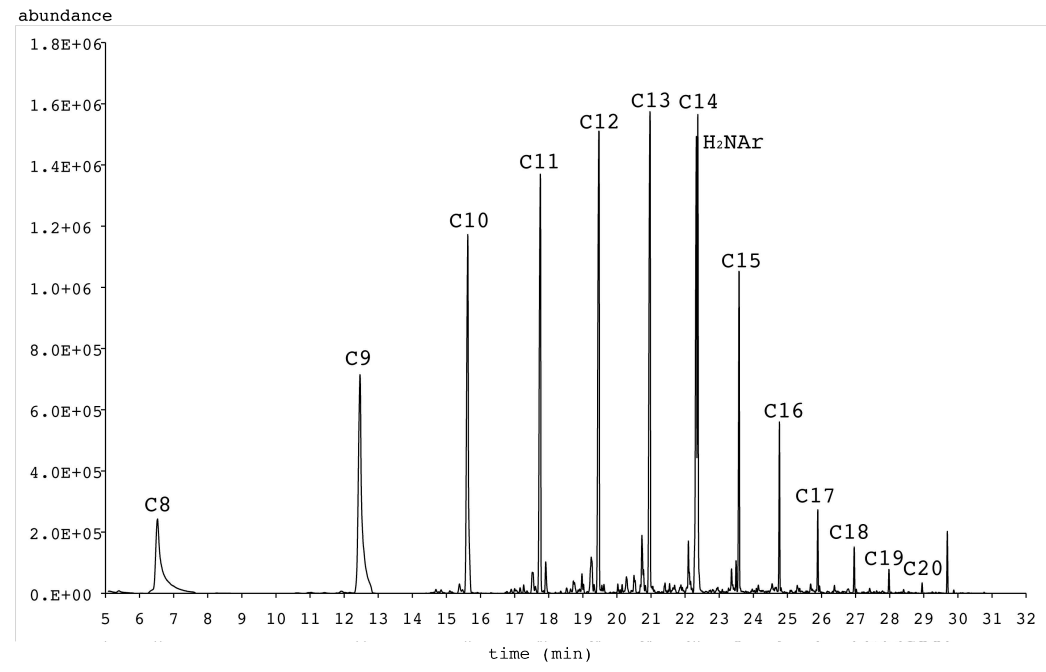

Figure 9. Reaction of 20 equiv of 1-octene with $\mathrm{Mo}(\mathrm{NAr})\left(\mathrm{CH}_{2} \mathrm{CH}_{2}\right)\left[\mathrm{OCH}\left(\mathrm{CF}_{3}\right)_{2}\right]_{2}\left(\mathrm{Et} \mathrm{O}_{2} \mathrm{O}\right)$ after one day at $100{ }^{\circ} \mathrm{C}$. (a) GC trace of the reaction mixture prior to hydrogenation. (b) GC trace of the reaction mixture after hydrogenation. 


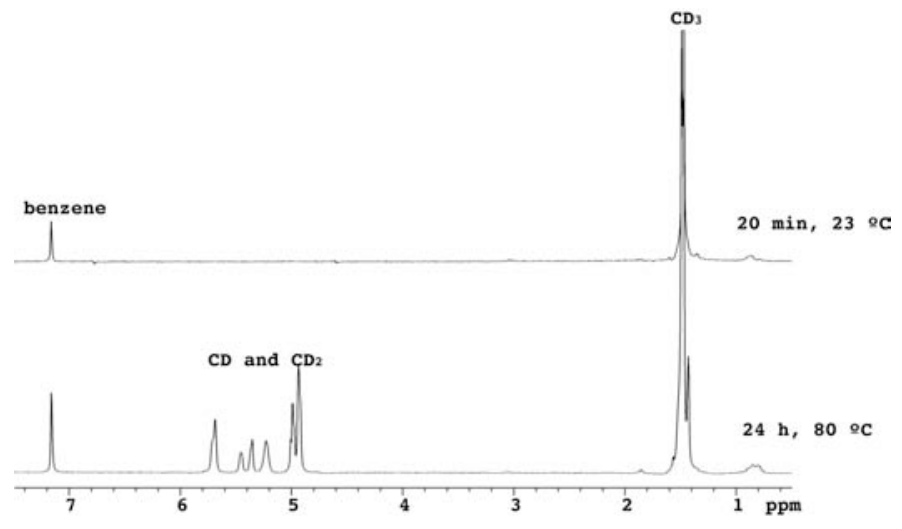

Figure 10. ${ }^{2} \mathrm{H}$ NMR spectrum of $\mathrm{Mo}(\mathrm{NAr})\left(\mathrm{CH}_{2} \mathrm{CH}_{2}\right)\left[\mathrm{OCH}\left(\mathrm{CF}_{3}\right)_{2}\right]_{2}\left(\mathrm{Et}_{2} \mathrm{O}\right)$ in benzene under $1 \mathrm{~atm}$ of $\mathrm{CD}_{3} \mathrm{CH}\left(\mathrm{CH}_{2}\right)$. From left to right: 7.16 (benzene), $5.69(1 \mathrm{H}), 5.45(0.33 \mathrm{H}), 5.35(0.46 \mathrm{H}), 5.23$ $(0.71 \mathrm{H}), 4.99(1.05 \mathrm{H}), 4.93(1.45 \mathrm{H}), 1.47(7.68 \mathrm{H}), 1.43(1.21 \mathrm{H}), 0.85(0.41 \mathrm{H})$. 


\section{References}

1. (a) Schrock, R. R. Chem.Rev. 2009, 109, 3211. (b) Schrock, R. R. Chem. Rev. 2002, 102, 145. (c) Schrock, R. R.; Hoveyda, A. H. Angew. Chem. Int. Ed. 2003, 42, 4592. (d) Schrock, R. R.; Czekelius, C. C. Adv. Syn. Catal. 2007, 349, 55. (e) Poater, A.; Solans-Monfort, X.; Clot, E.; Copéret, C.; Eisenstein, O. J. Am. Chem. Soc. 2007, 129, 8207.

2. Tsang, W. C. P.; Schrock, R. R.; Hoveyda, A. H. Organometallics 2001, 20, 5658.

3. Tsang, W. C. P.; Hultzsch, K. C.; Alexander,J. B.; Bonitatebus, P. J., Jr.; Schrock, R. R.; Hoveyda, A. H. J. Am. Chem. Soc. 2003, 125, 2652.

4. Tsang, W. C. P.; Jamieson, J. Y.; Aeilts, S. A.; Hultzsch, K. C.; Schrock, R. R.; Hoveyda, A. H. Organometallics 2004, 23, 1997.

5. Arndt, S.; Schrock, R. R.; Müller, P. Organometallics 2007, 26, 1279.

6. Jiang, A. J.; Schrock, R. R.; Müller, P. Organometallics 2008, 27, 4428.

7. Schrock, R. R.; Duval-Lungulescu, M.; Tsang, W. C. P.; Hoveyda, A. H. J. Am. Chem. Soc. 2004, 126, 1948.

8. Schrock, R. R.; Lopez, L. P. H.; Hafer, J.; Singh, R.; Sinha, A.; Müller, P. Organometallics $\mathbf{2 0 0 5}, 24,5211$.

9. (a) Singh, R.; Schrock, R. R.; Müller, P.; Hoveyda, A. H. J. Am. Chem. Soc. 2007, 129, 12654. (b) Marinescu, S. C.; Schrock, R. R.; Li, B.; Hoveyda, A. H. J. Am. Chem. Soc. 2009, 131, 58. (c) Malcolmson, S. J.; Meek, S. J.; Sattely, E. S.; Schrock, R. R.; Hoveyda, A. H. Nature 2008, 456, 933. (d) Sattely, E. S.; Meek, S. J.; Malcolmson, S. J.; Schrock, R. R.; Hoveyda, A. H. J. Am. Chem.Soc. 2009, 131, 943. (e) Schrock, R. R. Chem. Rev. 2009, 109, 3211. (f) Ibrahem, I; Yu, M.; Schrock, R. R.; Hoveyda, A. H. J. Am. Chem. Soc., 2009, 131, 3844. (g) Jiang, A. J.; Simpson, J. H.; Müller, P.; Schrock, R. R. J. Am. Chem. Soc. 2009, 131, 7770. (h) Meek, S. J.; Malcolmson, S. J.; Li, B.; Schrock, R. R.; Hoveyda, A. H. J. Am. Chem. Soc. 2009, 131, 16407. (i) Jiang, A. J.; Zhao, Y.; Schrock, R. R.; Hoveyda, A. H. J. Am. Chem. Soc. 2009, 131, 16630. (j) Flook, M. M.; Jiang, A. J.; Schrock, R. R.; Müller, P.; Hoveyda, A. H. J. Am. Chem. Soc. 2009, 131, 7962. (k) Lee, 
Y.-J.; Schrock, R. R.; Hoveyda, A. H. J. Am. Chem. Soc. 2009, 131, 10652. (1) Marinescu, S. C.;

Schrock, R. R.; Müller, P.; Hoveyda, A. H. J. Am. Chem. Soc. 2009, 131, 10840.

10. Solans-Monfort, X.; Copéret, C.; Eisenstein, O. J. Am. Chem. Soc. 2010, 132, 7750.

11. (a) Solans-Monfort, X.; Clot, E.; Copéret, C.; Eisenstein, O. J. Am. Chem. Soc. 2005, 127, 14015.

(b) Chabanas, M.; Baudouin, A.; Copéret, C.; Basset, J.-M. J. Am. Chem. Soc. 2001, 123, 2062.

12. R. Singh, Ph.D. thesis, MIT, 2008.

13. (a) McLain, S. J.; Schrock, R. R. J. Am. Chem. Soc. 1978, 100, 1315. (b) McLain, S. J.;

Sancho, J.; Schrock, R. R. J. Am. Chem. Soc. 1979, 101, 5451. (c) Schrock, R. R.; McLain, S. J.;

Sancho, J. Pure and Appl. Chem. 1980, 52, 729. (d) McLain, S. J.; Sancho, J.; Schrock, R. R. J. Am.

Chem. Soc. 1980, 102, 5610.

14. Miller, G. A.; Cooper, N. J. J. Am. Chem. Soc. 1985, 107, 709.

15. Freundlich, J. S.; Schrock, R. R.; Davis, W. M. J. Am. Chem. Soc. 1996, 118, 3643.

16. Hirsekorn, K. F.; Veige, A. S.; Marshak, M. P.; Koldobskaya, Y.; Wolczanski, P. T.;

Cundari, T. R.; Lobkovsky, E. B. J. Am. Chem. Soc. 2005, 127, 4809.

17. Schrock, R. R.; Luo, S.; Zanetti, N. C.; Fox, H. H. Organometallics 1994, 12, 3396.

18. Anders, U.; Nuyken, O.; Buchmeiser, M. R.; Wurst, K. Macromolecules 2002, 35, 9029.

19. Eppley, D. F.; Wolczanski, P. T.; Vanduyne, G. D. Angew. Chem. Int. Ed. 1991, 30, 584.

20. Ison, E. A.; Abboud K. A.; Boncella, J. M. Organometallics 2006, 25, 1557.

21. Wampler, K. M.; Schrock, R. R.; Hock, A. S. Organometallics 2007, 26, 6674.

22. (a) Feldman, J.; Davis, W. M.; Schrock, R. R. Organometallics 1989, 8, 2266. (b) Feldman,

J.; Davis, W. M.; Thomas, J. K.; Schrock, R. R. Organometallics 1990, 9, 2535. (c) Feldman J.;

Schrock, R. R. Prog. Inorg. Chem. 1991, 39, 1. (d) Bazan, G. C.; Oskam, J. H.; Cho, H.-N.; Park, L. Y.; Schrock, R. R. J. Am. Chem. Soc. 1991, 113, 6899.

23. Leduc, A.-M.; Salameh, A.; Soulivong, D.; Chabanas, M.; Basset, J.-M.; Copéret, C.; Solans-Monfort, X.; Clot, E.; Eisenstein, O.; Boehm, V. P. W.; Roeper, M. J. Am. Chem. Soc. 2008, $130,6288$. 
24. Organotransition metal chemistry; from bonding to catalysis, J. Hartwig, University Science Books, Sausalito, Califoria, 2010.

25. McLain, S. J.; Sancho, J.; Schrock, R. R. J. Am. Chem. Soc. 1979, 101, 5451.

26. Yang, G. K.; Bergman, R. G. Organometallics 1985, 4, 129.

27. (a) Kundu, S.; Choliy, Y.; Zhuo, G.; Ahuja, R.; Emge, T. J.; Warmuth, R.; Brookhart, M.; KroghJespersen, K.; Goldman, A. S. Organometallics 2009, 28, 5432. (b) Huang, Z. B., M.; Goldman, A. S.; Kundu, S.; Ray, A.; Scott, S. L.; Vicentec, B. C. Adv. Synth. Catal. 2009, 351, 188. (c) Bailey, B. C.; Schrock, R. R.; Kundu, S.; Goldman, A. S.; Huang, Z.; Brookhart, M. Organometallics 2009, $28,355$. 28. Sheldrick, G. M. Acta Cryst. 1990, A46, 467.

29. Sheldrick, G. M. Acta Cryst. 2008, A64, 112.

30. Müller, P. Crystallography Reviews 2009, 15, 57. 


\section{TOC}

Simple Molybdenum(IV) Olefin Complexes of the Type Mo(NR)(X)(Y)(olefin)

by

Smaranda C. Marinescu, Annie J. King, Richard R. Schrock*, Rojendra Singh,

Peter Müller, and Michael K. Takase

Simple Mo(IV) imido ethylene complexes can be prepared through exposure of imido alkylidene complexes to ethylene, and from these other olefin complexes (e.g., styrene and trans-3-hexene). All evidence suggests that alkene exchange and isomerization at the Mo(IV) center are facile, and that trace amounts of alkylidene complexes are formed that result in slow metathesis reactions to give a distribution of all possible olefins.

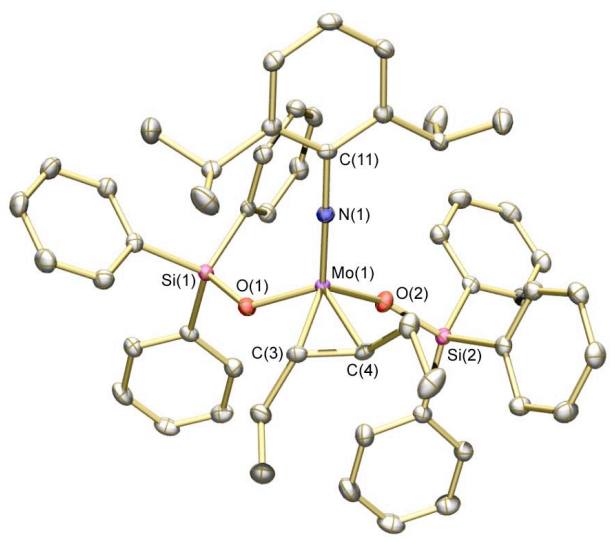

